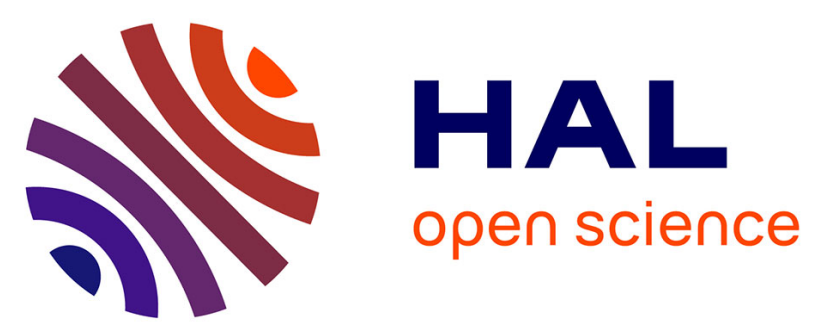

\title{
Synthesis, Structure, and Electrochemical Properties of Sterically Protected Molybdenum Trihydride Redox Pairs: A Paramagnetic "Stretched" Dihydrogen Complex?
}

Miguel Baya, Jennifer Houghton, Jean-Claude Daran, Rinaldo Poli, Louise

Male, Alberto Albinati, Matthias Gutman

\section{To cite this version:}

Miguel Baya, Jennifer Houghton, Jean-Claude Daran, Rinaldo Poli, Louise Male, et al.. Synthesis, Structure, and Electrochemical Properties of Sterically Protected Molybdenum Trihydride Redox Pairs: A Paramagnetic "Stretched" Dihydrogen Complex?. Chemistry - A European Journal, 2007, 13 (19), pp.5347-5359. 10.1002/chem.200700293 . hal-03194007

\section{HAL Id: hal-03194007 https://hal.science/hal-03194007}

Submitted on 9 Apr 2021

HAL is a multi-disciplinary open access archive for the deposit and dissemination of scientific research documents, whether they are published or not. The documents may come from teaching and research institutions in France or abroad, or from public or private research centers.
L'archive ouverte pluridisciplinaire HAL, est destinée au dépôt et à la diffusion de documents scientifiques de niveau recherche, publiés ou non, émanant des établissements d'enseignement et de recherche français ou étrangers, des laboratoires publics ou privés. 
Synthesis, structure and electrochemical properties of sterically protected molybdenum trihydride redox pairs: A paramagnetic "stretched" dihydrogen complex?

Miguel Baya, ${ }^{\mathrm{a}}$ Jennifer Houghton, ${ }^{\mathrm{a}}$ Jean-Claude Daran, ${ }^{\mathrm{a}}$ Rinaldo Poli, ${ }^{* \mathrm{a}}$ Louise Male, ${ }^{\mathrm{b}}$ Alberto Albinati ${ }^{\mathrm{b}}$ and Matthias Guttman, ${ }^{\mathrm{c}}$

${ }^{a}$ Laboratoire de Chimie de Coordination, UPR CNRS 8241 liée par convention à l'Université Paul Sabatier et à l'Institut National Polytechnique de Toulouse, 205 Route de Narbonne, 31077 Toulouse Cedex, France

${ }^{\mathrm{b}}$ Department of Structural Chemistry (DCSSI), Università di Milano, Via G. Venezian 21, 20133 Milano, Italy.

${ }^{\mathrm{c}}$ Rutherford Appleton Laboratory, ISIS Facility, Chilton (Didcot) OX11 OQX U.K..

Proofs to:

Rinaldo Poli

Tel: $+33-561333173$

Fax: $+33-561553003$

E-mail: poli@1cc-toulouse.fr 


\section{Summary}

Complexes $\mathrm{Cp}^{\#} \mathrm{Mo}\left(\mathrm{PMe}_{3}\right)_{2} \mathrm{H}_{3} \quad\left(\mathrm{Cp}^{\#}=1,2,4-\mathrm{C}_{5} \mathrm{H}_{2} t \mathrm{Bu}_{3}, \quad \mathbf{2 a} ; \quad \mathrm{C}_{5} \mathrm{Hi} \mathrm{Pr}_{4}, \quad 2 \mathbf{b}\right)$ have been synthesized from the corresponding compounds $\mathrm{Cp}^{\#} \mathrm{MoCl}_{4}(\mathbf{1 a}, \mathbf{1 b})$ and fully characterized, including by X-ray crystallography and by a neutron diffraction study for $\mathbf{2 a}$. Protonation of 2a led to complex $\left[\left(1,2,4-\mathrm{C}_{5} \mathrm{H}_{2} t \mathrm{Bu}_{3}\right) \mathrm{Mo}\left(\mathrm{PMe}_{3}\right)_{2} \mathrm{H}_{4}\right]^{+}$(3a) in THF and to $[(1,2,4-$ $\left.\mathrm{C}_{5} \mathrm{H}_{2}{ }^{\mathrm{t}} \mathrm{Bu}_{3}\right) \mathrm{Mo}\left(\mathrm{PMe}_{3}\right)_{2}\left(\mathrm{MeCN} \mathrm{H}_{2}\right]^{+}(\mathbf{4 a})$ in $\mathrm{MeCN}$. Complex $\mathbf{4 b}$ analogously derives from protonation of $\mathbf{2 b}$ in $\mathrm{MeCN}$, whereas the tetrahydride complex $\mathbf{3 b}$ is unstable. One-electron oxidation of $\mathbf{2 a}$ and $\mathbf{2} \mathbf{b}$ by $\left[\mathrm{Cp}_{2} \mathrm{Fe}\right] \mathrm{PF}_{6}$ produces the EPR active 17 -electron complexes $[\mathbf{2} \mathbf{a}]^{+}$ and $[\mathbf{2 b}]^{+}$. The former is thermally more stable than the latter and could be crystallographically characterized as the $\mathrm{PF}_{6}^{-}$salt by $\mathrm{X}$-ray diffraction, providing evidence for the presence of a stretched dihydrogen ligand $\left(\mathrm{H}^{\cdots} \mathrm{H}=1.36(6) \AA\right)$. Controlled thermal decomposition of $[\mathbf{2 a}]^{+}$yielded the product of $\mathrm{H}_{2}$ elimination, the 15-electron monohydride complex $\left[\left(1,2,4-\mathrm{C}_{5} \mathrm{H}_{2} t \mathrm{Bu}_{3}\right) \mathrm{Mo}\left(\mathrm{PMe}_{3}\right)_{2} \mathrm{H}_{3} \mathrm{PF}_{6}\right.$ (5a) which was characterized by $\mathrm{X}$-ray crystallography and by EPR spectroscopy at liquid $\mathrm{He}$ temperature. The compound establishes an equilibrium with the solvent adduct in THF. An electrochemical study by cyclic voltammetry provides further evidence for a rapid $\mathrm{H}_{2}$ elimination process from the 17electron complexes. Contrary to the previously investigated $\left[\mathrm{Cp} * \mathrm{Mo}(\mathrm{dppe}) \mathrm{H}_{3}\right]^{+}$system, the decomposition of $[\mathbf{2 a}]^{+}$by $\mathrm{H}_{2}$ substitution with a solvent molecule appears to follow a dissociative pathway in $\mathrm{MeCN}$.

\section{Keywords}

Molybdenum, bulky cyclopentadienyl ligands, hydride ligands, paramagnetic hydride complexes, oxidatively induced reductive elimination, neutron diffraction 


\section{Introduction}

Hydride complexes have paramount importance in light of their implication in a variety of catalytic processes and as models of a number of biological functions such as hydrogenase and nitrogenase. ${ }^{[1-6]}$ Because of the strong covalent nature of the $\mathrm{M}-\mathrm{H} \sigma$ bond and the absence of additional orbital interactions (i.e. of $\pi$ type), they are usually stable only in a closed-shell configuration. Open-shell versions are reactive, which is the very reason for their involvement as catalytic intermediates. An interesting subclass of open-shell hydride complexes are those with an odd-electron (mostly 17-electron) configuration, characterized by paramagnetism. These complexes have generally been accessed by one-electron oxidation of stable diamagnetic precursors. In most cases, they decompose by deprotonation, ${ }^{[7]}$ disproportionation, ${ }^{[8]}$ dihydrogen reductive elimination (for complexes containing at least two hydride ligands), ${ }^{[9]}$ atom transfer, ${ }^{[10]}$ and other pathways. ${ }^{[1]}$ This multitude of available reaction pathways complicates their potential application, for instance in electrocatalysis. It is therefore useful to investigate in greater detail how the various pathways depend on the reaction conditions (e.g. solvent, available substrates) and molecular parameters (e.g. stereoelectronic properties of the ligand environment). For this purpose, it is necessary to develop more stable systems. We have learned from previous investigations ${ }^{[9,12-16]}$ that all decomposition pathways are disfavored by both a stronger electron donating and more sterically protecting ligand environment.

The oxidation of $\mathrm{Cp} * \mathrm{Mo}(\mathrm{dppe}) \mathrm{H}_{3}$ (dppe $=\mathrm{Ph}_{2} \mathrm{PCH}_{2} \mathrm{CH}_{2} \mathrm{PPh}_{2}$ ) was studied in the greatest detail. ${ }^{[9,12,16]}$ It leads to the paramagnetic complex $\left[\mathrm{Cp} * \mathrm{Mo}(\mathrm{dppe}) \mathrm{H}_{3}\right]^{+}$, which is stable at low temperatures and was characterized in situ by EPR spectroscopy. The detailed investigation of its decomposition at room temperature enabled us to quantify the relative rates of deprotonation (by the residual neutral precursor), disproportionation, and $\mathrm{H}_{2}$ 
elimination in various solvents. ${ }^{[9,16]}$ This was the first reported example where $\mathrm{H}_{2}$ oxidatively induced reductive elimination could be unambiguously demonstrated and distinguished from other decomposition pathways. Oxidation of a polyhydride complex $\left\{\mathrm{MH}_{\mathrm{n}}\right\}$ is expected to favor its rearrangement to a nonclassical isomer, $\left\{\mathrm{MH}_{\mathrm{n}-2}\left(\mathrm{H}_{2}\right)\right\}^{+},{ }^{[17,18]}$ but the multitude of decomposition pathways, all possibly leading to $\mathrm{H}_{2}$ evolution, ${ }^{[19]}$ have previously made the identification of the $\mathrm{H}_{2}$ elimination pathway uncertain. ${ }^{[1,20]}$ For this specific trihydrido molybdenum complex all three decomposition pathways were shown to occur via the nonclassical intermediate $\left[\mathrm{Cp} * \mathrm{Mo}(\mathrm{dppe}) \mathrm{H}\left(\mathrm{H}_{2}\right)\right]^{+}$, although theoretical calculations and circumstantial evidence indicates that the oxidized complex adopts a classical structure. Since the nonclassical tautomer is energetically less accessible for the related tungsten system, complex $\left[\mathrm{Cp}^{*} \mathrm{~W}(\mathrm{dppe}) \mathrm{H}_{3}\right]^{+}$turned out to be sufficiently stable to be isolated and crystallographically characterized. ${ }^{[9]}$

In this contribution, we report the synthesis and investigations into new molybdenum systems, isoelectronic with $\mathrm{Cp} * \mathrm{Mo}(\mathrm{dppe}) \mathrm{H}_{3}$, that contain an even more strongly donating and sterically encumbering coordination sphere. We used the two highly substituted cyclopentadienyl rings, $\mathrm{C}_{5} \mathrm{HiPr}_{4}$ and $1,2,4-\mathrm{C}_{5} \mathrm{H}_{2} t \mathrm{Bu}_{3}$, in place of $\mathrm{Cp}^{*}$ and two $\mathrm{PMe}_{3}$ ligands in place of bidentate dppe. Notable results of this investigation have been the isolation and structural characterization of the 17-electron oxidation product, $[(1,2,4-$ $\left.\left.\mathrm{C}_{5} \mathrm{H}_{2} t \mathrm{Bu}_{3}\right) \mathrm{Mo}\left(\mathrm{PMe}_{3}\right)_{2} \mathrm{H}_{3}\right]^{+}$, and the observation of its subsequent $\mathrm{H}_{2}$ elimination process leading to the 15-electron monohydride derivative, $\left[\left(1,2,4-\mathrm{C}_{5} \mathrm{H}_{2} t \mathrm{Bu}_{3}\right) \mathrm{Mo}\left(\mathrm{PMe}_{3}\right)_{2} \mathrm{H}\right]^{+}$, which was also structurally characterized. Some aspects of this investigation have been recently communicated. ${ }^{[21]}$ While those preliminary results will be reported again here in fuller details, stronger emphasis will be placed on complementary investigations that have not previously been described. 


\section{Results and Discussion}

(a) Synthesis and characterization of the diamagnetic trihydride complexes $\mathrm{Cp}^{\#} \mathrm{Mo}\left(\mathrm{PMe}_{2}\right)_{2} \mathrm{H}_{3}\left(\mathrm{Cp}^{\#}=\right.$ 1,2,4-C5 $\left.\mathrm{H}_{2} t \mathrm{Bu} 3,2 \mathrm{a} ; \mathrm{C}_{5} \mathrm{HiPr}_{4}, 2 \mathrm{~b}\right)$

Adaptation of Schrock's $\mathrm{Cp}^{*} \mathrm{MoCl}_{4}$ synthetic procedure ${ }^{[22,23]}$ to the bulkier $\mathrm{Cp}^{\#}$ analogues $\left(\mathrm{Cp}^{\#}=1,2,4-\mathrm{C}_{5} \mathrm{H}_{2} t \mathrm{Bu}_{3}, \mathbf{a}\right.$, and $\left.\mathrm{C}_{5} \mathrm{H} i \mathrm{Pr}_{4}, \mathbf{b}\right)$ yielded the corresponding $\mathrm{Cp}^{\#} \mathrm{MoCl}_{4}$ derivatives $\mathbf{1 a}$ and $\mathbf{1 b}$ in good yields, see Scheme 1. Subsequent reaction of these compounds with $\mathrm{LiAlH}_{4}$ in the presence of $\geq 2$ equivalents of $\mathrm{PMe}_{3}$, followed by methanolysis and crystallization from ether, yielded the corresponding trihydride derivatives, $\mathrm{Cp} \mathrm{p}^{\#} \mathrm{Mo}\left(\mathrm{PMe}_{3}\right)_{2} \mathrm{H}_{3}$, $\mathbf{2 a}$ and $\mathbf{2} \mathbf{b}$. It is interesting to compare these results with that previously reported for the related $\mathrm{Cp}^{*}$ system, which led to a mixture of $\mathrm{Cp} * \mathrm{Mo}\left(\mathrm{PMe}_{3}\right)_{2} \mathrm{H}_{3}$ and $\mathrm{Cp}^{*} \mathrm{Mo}\left(\mathrm{PMe}_{3}\right)_{3} \mathrm{H}^{[24]}$ The bulkier $\mathrm{Cp}^{\#}$ systems afford the trihydride derivatives $\mathbf{2}$ selectively and show no tendency to replace $\mathrm{H}_{2}$ in the presence of excess $\mathrm{PMe}_{3}$ under thermolytic conditions.

$$
\begin{aligned}
& \mathrm{Mo}(\mathrm{CO})_{6}+\mathrm{Na}^{+} \mathrm{Cp}^{\#-} \stackrel{\mathrm{THF} / \Delta}{\longrightarrow} \mathrm{Cp}^{\#} \mathrm{Mo}(\mathrm{CO})_{3}{ }^{-\mathrm{Na}^{+}} \underset{\operatorname{room~T}}{\stackrel{\mathrm{MeI} / \mathrm{THF}}{\longrightarrow}} \mathrm{Cp}{ }^{\#} \mathrm{Mo}(\mathrm{CO})_{3}\left(\mathrm{CH}_{3}\right) \\
& \stackrel{\mathrm{PhICl}_{2} / \mathrm{CH}_{2} \mathrm{Cl}_{2}}{\longrightarrow} \mathrm{Cp}^{\#} \mathrm{MoCl}_{4} \underset{2}{\stackrel{1 . \mathrm{LiAlH}_{4} / \mathrm{PMe}_{3} / \mathrm{THF}}{2} \mathrm{MeOH}} \mathrm{Cp}^{\#} \mathrm{Mo}\left(\mathrm{PMe}_{3}\right)_{2} \mathrm{H}_{3}
\end{aligned}
$$

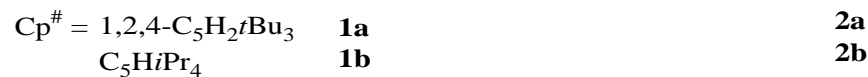

\section{Scheme 1}

Both compounds gave single crystals suitable for a structural analysis. The crystal of $\mathbf{2 a}$ had sufficient quality to allow the location and refinement of the hydride positions from the $\mathrm{X}$-ray data, as shown in the previous communication. ${ }^{[21]}$ We have now completed the structural investigation with a neutron diffraction experiment for $\mathbf{2 a}$ (the results of both refinements are compared in Table 1) and an X-ray diffraction experiment for $\mathbf{2 b}$. The latter 
crystals had poorer quality and the hydride positions could not be located; the observable structural parameters are very close to those of $\mathbf{2 a}$, see Table 1. A view of both geometries is shown in Figure 1. The molecular geometry is unusual for a half sandwich (ring)MoX $\mathrm{X}_{3} \mathrm{~L}_{2}$ compound, but parallels that previously reported for the related $\mathrm{Cp}^{*} \mathrm{MoH}_{3}(\mathrm{dppe})$ compound. ${ }^{[25,26]}$ This demonstrates that the unusual structure observed for $\mathrm{Cp}^{*} \mathrm{MoH}_{3}(\mathrm{dppe})$ is not enforced by the chelating nature of the dppe ligand. Another example for this structural type has recently been reported for the isoelectronic compound $\mathrm{Cp} * \mathrm{~W}(\mathrm{CO})_{2} \mathrm{H}_{2}\left(\mathrm{SiH}_{2} \mathrm{Ph}\right){ }^{[27]}$ As expected, the X-ray diffraction experiment yields shorter Mo-H distances than the neutron diffraction experiment for compound 2a. Only those afforded by neutron diffraction should be considered reliable. The parameters that do not involve hydrogen atom positions, on the other hand, are more precisely determined by the X-ray diffraction experiment.

The most interesting structural feature is the distance between atoms $\mathrm{H} 2$ and $\mathrm{H} 3$ [1.69(2) $\AA$ from the neutron structure]. This value is too long to envisage an interaction, but short in comparison to most nonbonded distances recorded by neutron diffraction for polyhydride complexes. This is evidence for a certain degree of "compression". ${ }^{[28]}$ Other relatively short nonbonded $\mathrm{H} \cdots \mathrm{H}$ separations are $1.67(1)$ and $1.70(1) \quad \AA \quad$ in $\left[\mathrm{CpIr}\left(\mathrm{PMe}_{3}\right) \mathrm{H}_{3}\right]^{+},{ }^{[29]}$ and values ranging from $1.637(4)$ to $1.668(4) \AA$ between adjacent $\mathrm{H}$ atoms in compound $\mathrm{Os}\left(\mathrm{PiPr}_{2} \mathrm{Ph}\right)_{2} \mathrm{H}_{6},{ }^{[30]}$ whereas there are no shorter intramolecular $\mathrm{H} \cdots \mathrm{H}$ separations than $1.77 \AA$ in compound $\mathrm{Re}(\mathrm{dppe}) \mathrm{H}_{7 \cdot}{ }^{[31]}$ The longest $\mathrm{H}-\mathrm{H}$ separations in compounds that have been defined as "stretched $\mathrm{H}_{2}$ complexes" are 1.357(7) $\AA$ in $\mathrm{ReH}_{7}\left(\mathrm{P}\left(\mathrm{C}_{6} \mathrm{H}_{4}-p-\mathrm{CH}_{3}\right)_{3}\right)_{2}{ }^{[32]}$ and 1.34(2) in $\left[\mathrm{Os}\left(\mathrm{H}_{2}\right)(\mathrm{en})_{2}\left(\mathrm{O}_{2} \mathrm{CMe}\right)\right]^{+} \mathrm{PF}_{6}{ }^{-[33]}$ all these values resulting again from neutron diffraction experiments. Finally, complex $\mathrm{OsH}_{5}\left(\mathrm{PMe}_{2} \mathrm{Ph}\right)_{3}{ }^{+}$ exhibits an even longer separation (1.49(4) $\AA$ ) and was described as falling in a "gray" region where there may or may not be a direct $\mathrm{H} / \mathrm{H}$ attractive interaction. ${ }^{[34]}$ The Cambridge Crystallographic Structural Database does not reveal H-H contacts between 1.0 and $1.7 \AA$ for 
Mo complexes, but a distance of ca. $1.18 \AA$ has recently been estimated from $\mathrm{T}_{1}$ and $J_{\mathrm{HD}}$ measurements for complex $\left[\mathrm{Mo}(\mathrm{NPh})\left(\mathrm{PMe}_{3}\right)_{2}\left(\mathrm{H}_{2}\right)\left(o-\left(\mathrm{Me}_{3} \mathrm{SiN}\right)_{2} \mathrm{C}_{6} \mathrm{H}_{4}\right)\right] .^{[35]} \quad$ Interestingly, if the $\mathrm{H} 2$ and $\mathrm{H} 3$ atoms are considered as defining a stretched $\mathrm{H}_{2}$ ligand, therefore occupying a single coordination position in a Mo ${ }^{\mathrm{II}}$ complex, then the coordination geometry would be described as a "four-legged piano stool", which is indeed a quite common geometrical arrangement for $\mathrm{Mo}^{\mathrm{II}},{ }^{[36]}$ as exemplified by $\mathrm{CpMo}\left(\mathrm{PMe}_{2} \mathrm{Ph}\right)_{3} \mathrm{Cl}^{[37]}$ and $\mathrm{CpMo}(\mathrm{dppe})(\mathrm{CO}) \mathrm{H}^{[38]}$

$<$ Table 1>
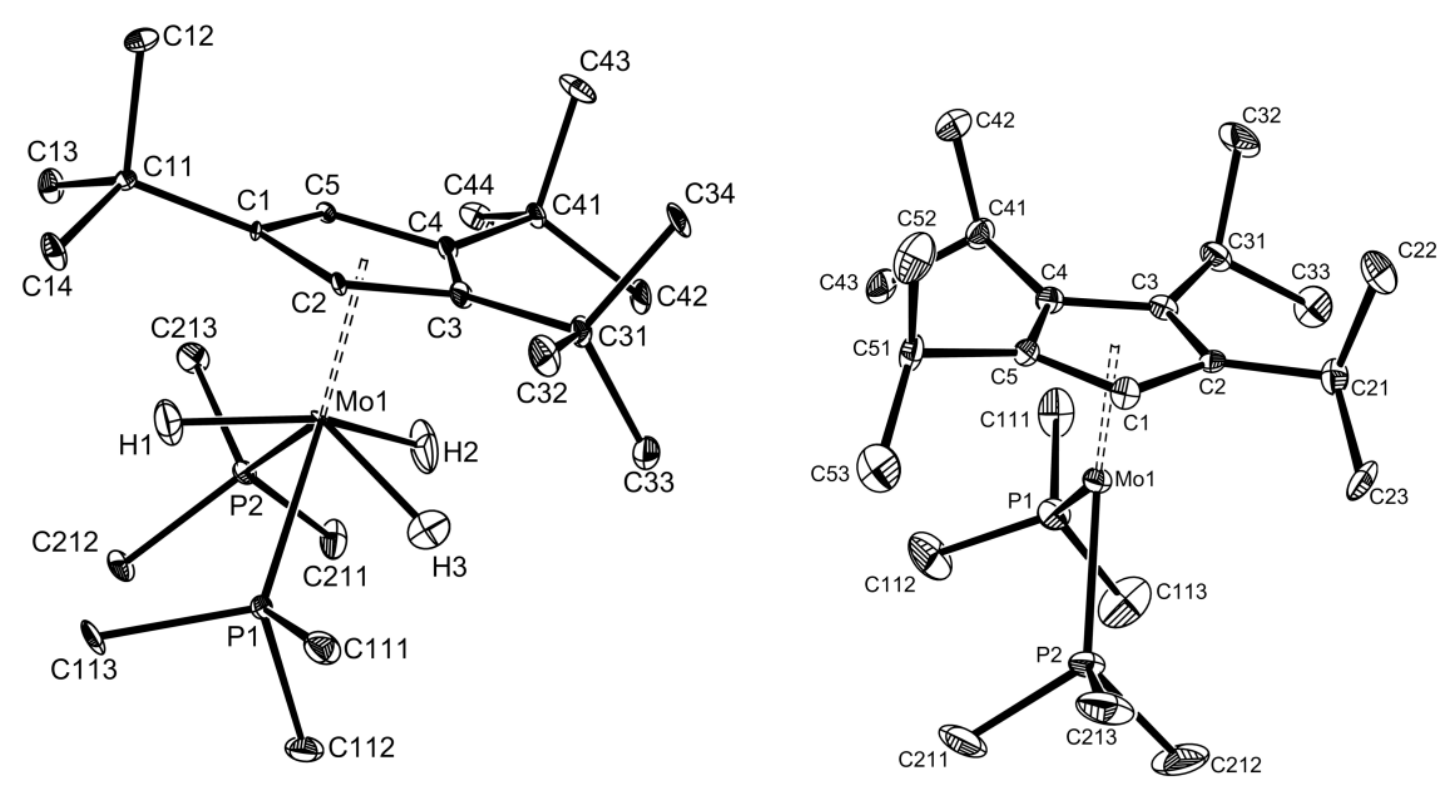

Figure 1. ORTEP view of compounds $\mathbf{2 a}$ (neutron diffraction, left) and $\mathbf{2 b}$ (right). Hydrogen atoms, except those directly bonded to the Mo atom in compound 2a, are not shown for clarity.

The NMR properties of $\mathbf{2 a}$ and $\mathbf{2} \mathbf{b}$ confirm the presence of three hydride ligands. The single ${ }^{31} \mathrm{P}\left\{{ }^{1} \mathrm{H}\right\}$ resonance observed at room temperature is transformed into a binomial quartet in ${ }^{31} \mathrm{P}\left\{\right.$ sel. $\left.{ }^{1} \mathrm{H}\right\}$ NMR experiment, showing that the $\mathrm{P}$ nuclei are coupled to three equivalent protons. In addition, the ${ }^{1} \mathrm{H}$ spectrum shows a single, sharp triplet resonance. A rapid 
exchange process between the inequivalent hydride positions must therefore be present. For the related $\mathrm{Cp} * \mathrm{Mo}(\mathrm{dppe}) \mathrm{H}_{3}$ compound, the fluxional process could not be frozen out even at the lowest attainable temperatures. ${ }^{[26]}$ For compounds $\mathbf{2 a}$ and $\mathbf{2 b}$, on the other hand, cooling results in decoalescence for the ${ }^{1} \mathrm{H}$ NMR signal to yield two signals in a 1:2 ratio, consistent with the solid state structural investigation, see Figure 2. This shows quite clearly the effect of the bulky ring substituents on the dynamics of the hydride exchange process. For compound 2a, the lowest temperature (193 K) spectrum displayed well resolved triplets, due to coupling to the two equivalent $\mathrm{P}$ donor nuclei, with the unique hydride ligand being characterized by a greater $\mathrm{J}_{\mathrm{HP}}(64 \mathrm{~Hz})$, relative to the two equivalent ones $(44 \mathrm{~Hz})$. No $\mathrm{H}-\mathrm{H}$ coupling between the inequivalent hydrides can be discerned. For compound $\mathbf{2 b}$, on the other hand, the spectrum remained rather broad even at $193 \mathrm{~K}$. A lineshape analysis yielded the activation parameters of the hydride scrambling process as $\Delta \mathrm{H}^{\ddagger}=9.0 \pm 0.7(\mathbf{2 a})$ and $8.5 \pm 0.3$ (2b) $\mathrm{kcal} \mathrm{mol}^{-1} ; \Delta \mathrm{S}^{\ddagger}=17 \pm 3(\mathbf{2 a})$ and $21 \pm 1$ (2b) e.u. The similar values of both activation parameters for the two compounds are in line with the similar structure of the two compounds. The longitudinal relaxation times $\left(\mathrm{T}_{1}\right)$ of the various signals are also shown in Figure 2. They confirm the classical nature of the compounds. Most notably, for compound 2a, the $T_{1}$ value for the equivalent hydride ligands signal is not significantly shorter than that of the unique hydride resonance below the decoalescence temperature. 

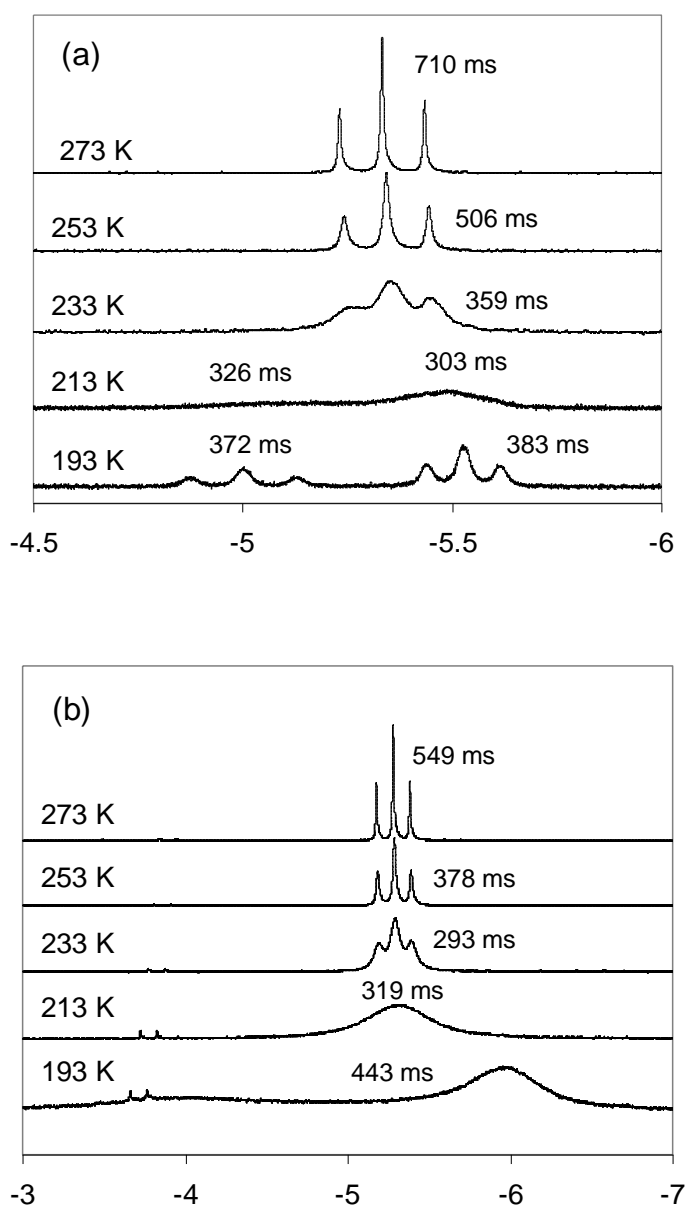

Figure 2. Variable temperature ${ }^{1} \mathrm{H}$ NMR spectrum of (a) compound 2a and (b) compound $\mathbf{2 b}$ in the hydride resonance region. The individual temperatures are shown on each spectrum and the time values shown are the longitudinal relaxation times of the corresponding resonance.

The ${ }^{31} \mathrm{P}$ NMR resonance of the two phosphine ligands remained sharp in the entire temperature range for compound $\mathbf{2 a}$, in agreement with the chemical equivalence shown by the X-ray structure. For compound $\mathbf{2 b}$, on the other hand, a decoalescence phenomenon was observed at low temperatures, yielding two singlet resonances with approximately equal intensities at $\delta 15.9$ and 12.3 at $193 \mathrm{~K}$ (Figure shown in the Supporting Information). This behaviour can be rationalized by either the freezing out of a single Mo- $\left(\mathrm{C}_{5} \mathrm{H} i \mathrm{Pr}_{4}\right)$ rotamer with symmetry inequivalent $\mathrm{PMe}_{3}$ donors (but these ligands also need to be characterized by a small enough P-P coupling since this is not observed at $193 \mathrm{~K}$ ), or by the presence of two 
equilibrating rotamers having similar energy, perhaps differing by the relative conformation of the $i \mathrm{Pr}$ groups in the $\mathrm{C}_{5} \mathrm{HiPr} 4$ ring. The latter phenomenon would not be expected to lead to the existence of different rotamers for the $1,2,4-\mathrm{C}_{5} \mathrm{H}_{2} t \mathrm{Bu}_{3}$ substituted complex.

\section{(b) Protonation studies}

Compound $2 \mathrm{a}$ reacts with $\mathrm{HBF}_{4}$ at $-80^{\circ} \mathrm{C}$ in $\mathrm{THF}$ to yield the tetrahydride complex $\left[\left(1,2,4-\mathrm{C}_{5} \mathrm{H}_{2} t \mathrm{Bu}_{3}\right) \mathrm{MoH}_{4}\left(\mathrm{PMe}_{3}\right)_{2}\right]^{+} \mathrm{BF}_{4}^{-}, 3 \mathbf{3}$, see Scheme 2. This product is related to the previously described $\left[\mathrm{Cp} * \mathrm{Mo}(\mathrm{dppe}) \mathrm{H}_{4}\right]^{+},{ }^{[26]}$ but shows a much greater thermal stability. It is stable in THF solution at room temperature, whereas complex $\left[\mathrm{Cp}^{*} \mathrm{Mo}(\mathrm{dppe}) \mathrm{H}_{4}\right]^{+}$ decomposes rapidly by loss of $\mathrm{H}_{2}$ via a presumed nonclassical $\left[\mathrm{Cp} * \mathrm{Mo}(\mathrm{dppe})\left(\mathrm{H}_{2}\right) \mathrm{H}_{2}\right]^{+}$ intermediate. This stabilization effect is probably related to the greater donor power of the coordination sphere in $\mathbf{3 a}$ relative to $\left[\mathrm{Cp} * \mathrm{Mo}(\mathrm{dppe}) \mathrm{H}_{4}\right]^{+}$, with the corresponding stabilization of the classical tetrahydrido structure with respect to the nonclassical tautomer. Compound 3a is diamagnetic and colorless, as expected for the $d^{0}$ configuration of formally hexavalent molybdenum. It features, as expected, a triplet hydride signal in the ${ }^{1} \mathrm{H}$ NMR spectrum (at $4.2 \mathrm{ppm}$ ) and a singlet (at $0.6 \mathrm{ppm}$ ) in the ${ }^{31} \mathrm{P}\left\{{ }^{1} \mathrm{H}\right\}$ NMR spectrum. Selective irradiation of the $\mathrm{PMe}_{3}$ proton resonance yields a quintet ${ }^{31} \mathrm{P}$ signal, in agreement with the presence of four hydride ligands. The compound has also been structurally characterized by single crystal Xray diffraction.

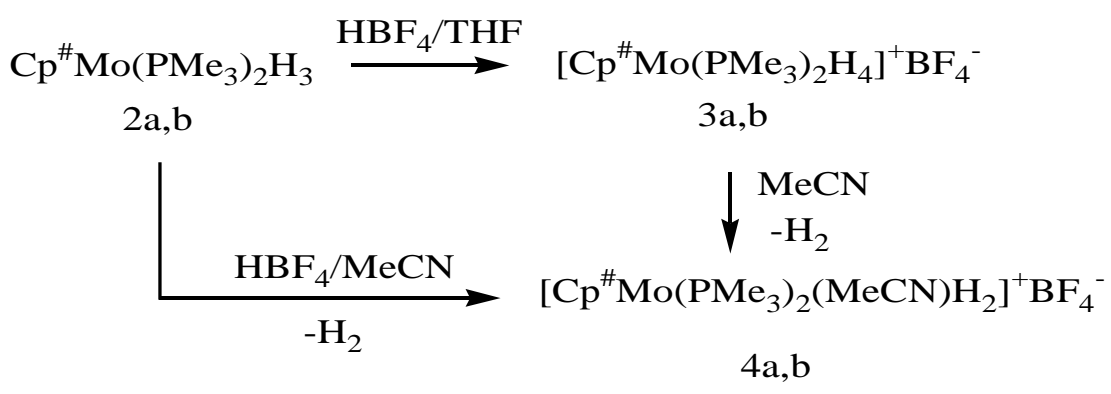

\section{Scheme 2}


The cation geometry is illustrated in Figure 3. The crystal quality allowed the location and refinement of all four hydride ligands. The geometry of the tetrahydride cation can be described as a highly distorted pentagonal bipyramid, when the bulky $\left(1,2,4-\mathrm{C}_{5} \mathrm{H}_{2} t \mathrm{Bu}_{3}\right)$ ligand is considered to occupy a single coordination position at one of the vertices of the bipyramid. The second axial position is occupied by the hydride ligand $\mathrm{H} 4$, with the 5 equatorial ligands bent toward $\mathrm{H} 4$ and away from the cyclopentadienyl ligand (especially the two phosphine ligands, for steric reasons). The two $\mathrm{PMe}_{3}$ ligands occupy 1,3 positions in the pseudopentagonal plane, with atom $\mathrm{H} 1$ bisecting the P1-Mo-P2 angle. The related complex $\left[\mathrm{Cp}^{*} \mathrm{~W}(\mathrm{dppe}) \mathrm{H}_{4}\right]^{+}$was found to adopt an analogous coordination geometry, with the chelating dppe ligand occupying one equatorial and one axial site. ${ }^{[26]}$

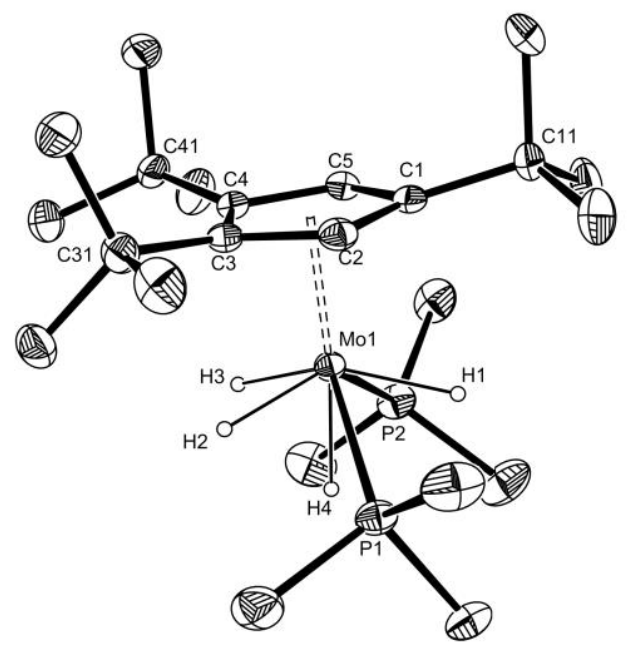

Figure 3. ORTEP view of the cation in compound 3a. Hydrogen atoms, except those directly bonded to the Mo atom, are not shown for clarity.

The cationic tetrahydride complex $\mathbf{3 a}$ was also formed by protonation of $\mathbf{2 a}$ with $\mathrm{HBF}_{4}$ in $\mathrm{MeCN}$, but further rapid evolution took place in this case. This reaction was only carried out on a spectroscopic scale in $\mathrm{CD}_{3} \mathrm{CN}$ and the resulting solution was monitored with time by 
${ }^{1} \mathrm{H}$ and ${ }^{31} \mathrm{P}$ NMR spectroscopy. Within minutes at room temperature, resonances corresponding to a second complex began to appear and the conversion was complete in $5 \mathrm{~h}$. This product, $\quad\left[\left(1,2,4-\mathrm{C}_{5} \mathrm{H}_{2}{ }^{\mathrm{t}} \mathrm{Bu}_{3}\right) \mathrm{Mo}\left(\mathrm{PMe}_{3}\right)_{2}(\mathrm{MeCN}) \mathrm{H}_{2}\right]^{+}, \quad \mathbf{4 a}, \quad$ derives from $\mathrm{H}_{2}$ elimination/MeCN coordination from 3a. It displays a singlet ${ }^{31} \mathrm{P}\left\{{ }^{1} \mathrm{H}\right\}$ resonance at $1.85 \mathrm{ppm}$, which converts into a triplet upon selective decoupling of the $\mathrm{PMe}_{3}$ ligand ${ }^{1} \mathrm{H}$ resonance. At room temperature a single broad hydride resonance is observed, however on cooling a $\mathrm{CD}_{3} \mathrm{CN}$ solution to $-40^{\circ} \mathrm{C}$, two triplet hydride resonances are resolved at -0.27 and $-6.77 \mathrm{ppm}$ respectively. This suggests that the two $\mathrm{PMe}_{3}$ ligands occupy equivalent positions at all temperatures, consistent with the structure shown in $\mathbf{I}$.

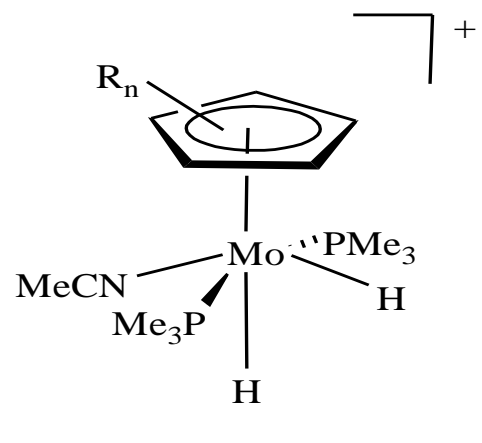

I $\quad \mathrm{R}_{\mathrm{n}}=1,2,4-t \mathrm{Bu}_{3}, i \mathrm{Pr}_{4}$

The corresponding reaction of $\mathbf{2} \mathbf{b}$, when carried out in $\mathrm{THF}$ at $-80^{\circ} \mathrm{C}$, led to the precipitation of a white solid, presumably corresponding to the $\left[\left(\mathrm{C}_{5} \mathrm{Hi} \mathrm{Pr}_{4}\right) \mathrm{Mo}\left(\mathrm{PMe}_{3}\right)_{2} \mathrm{H}_{4}\right]^{+}$ complex, 3b. However, this compound decomposes, even in the solid state, when warmed up to room temperature. Therefore, it could not be spectroscopically characterized. When the same protonation reaction was carried out in acetonitrile, the formation of complex $\left[\left(\mathrm{C}_{5} \mathrm{H} i \mathrm{Pr}_{4}\right) \mathrm{Mo}\left(\mathrm{PMe}_{3}\right)_{2}(\mathrm{MeCN}) \mathrm{H}_{2}\right]^{+}, \mathbf{4 b}$, could be observed. As with $\mathbf{4 a}$, the hydride ligands in complex $\mathbf{4 b}$ are involved in a fluxional process at room temperature, appearing as a very broad resonance at $-2.5 \mathrm{ppm}$. On cooling to $200 \mathrm{~K}$ in acetone- $d_{6}$, two doublet of triplet resonances decoalesce, at -0.13 and -5.27 ppm respectively, confirming that each hydride 
ligand couples to two equivalent phosphorus nuclei and to the other hydride ligand, in agreement with structure I. At this temperature, all four isopropyl groups on the cyclopentadienyl moiety also become inequivalent. In both complexes $\mathbf{4}$, a resonance integrating to 3 protons, assigned to the coordinated $\mathrm{MeCN}$, can be observed at $\delta 2.17$ (for $\mathbf{4 a}$ in $\mathrm{CD}_{3} \mathrm{CN}$ ) and 2.71 (for $\mathbf{4 b}$ in acetone- $d_{6}$ ). This behaviour is analogous to that of the related $\mathrm{Cp}^{*} \mathrm{Mo}(\mathrm{dppe}) \mathrm{H}_{3}$ complex. ${ }^{[26]}$ The greater coordinating ability of the acetonitrile solvent induces a more facile $\mathrm{H}_{2}$ elimination by more efficiently trapping the resulting 16-electron fragment.

\section{(c) Oxidation studies: isolation and characterization}

Preliminary electrochemical investigations indicated that both complexes $\mathbf{2 a , b}$ undergo an electrochemically reversible one-electron oxidation process and suggested that the oxidation product is relatively stable. The electrochemical behavior will be analysed in more detail later in section (e). The stoichiometric oxidation was accomplished by the use of $\mathrm{Cp}_{2} \mathrm{Fe}^{+} \mathrm{PF}_{6}{ }^{-}$in THF, see Scheme 3. The product for the $1,2,4-\mathrm{C}_{5} \mathrm{H}_{2} t \mathrm{Bu}_{3}$ system was sufficiently stable to be isolated and crystallized. Its X-ray structure and its EPR spectrum (Figure 4) demonstrate its chemical identity as the $\mathrm{PF}_{6}^{-}$salt of the one-electron oxidation product, $[\mathbf{2 a}]^{+}$, as discussed previously. ${ }^{[21]}$

$$
\begin{aligned}
& \mathrm{Cp}^{\#} \mathrm{Mo}\left(\mathrm{PMe}_{3}\right)_{2} \mathrm{H}_{3} \stackrel{\left[\mathrm{Cp}_{2} \mathrm{Fe}\right]^{+} \mathrm{PF}_{6}^{-}}{\longrightarrow}\left[\mathrm{Cp}^{\#} \mathrm{Mo}\left(\mathrm{PMe}_{3}\right)_{2} \mathrm{H}_{3}\right]^{+} \mathrm{PF}_{6}^{-} \\
& \mathrm{Cp}^{\#}=1,2,4-\mathrm{C}_{5} \mathrm{H}_{2} t \mathrm{Bu}_{3}\left([\mathbf{2 a}]^{+} \mathrm{PF}_{6}^{-}\right) \\
& \mathrm{C}_{5} \mathrm{HiPr}_{4} \quad\left([2 \mathbf{b}]^{+} \mathrm{PF}_{6}{ }^{-}\right)
\end{aligned}
$$

\section{Scheme 3}




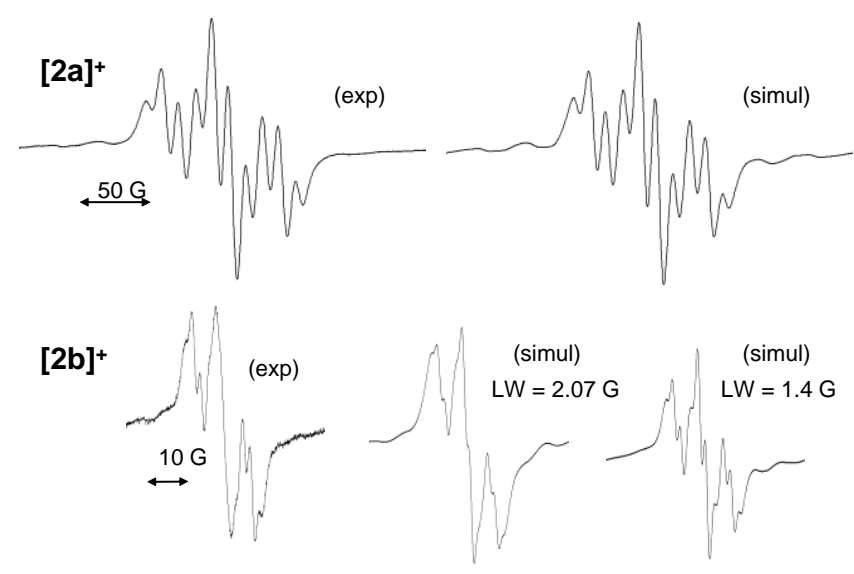

Figure 4. EPR spectra of complexes $[\mathbf{2}]^{+}$in THF solution. Above: complex $[\mathbf{2 a}]^{+}(\mathrm{T}=193)$. Below: complex $[\mathbf{2 b}]^{+}(\mathrm{T}=183)$.

The most relevant metric parameters of the $[\mathbf{2 a}]^{+}$structure are compared with those of the parent compound 2a in Table 1. The overall geometry of the cation is essentially unchanged relative to that of the neutral precursor (see the previous communication for an ORTEP view). ${ }^{[21]}$ There is no evidence of an interaction between the two ions, notably hydrogen bonding between the hydride ligands and the fluorine atoms of the anion. The MoCNT distance is slightly shorter, whereas the Mo-P distances is slightly longer, relative to the neutral precursor. The most notable change is a decrease of the $\mathrm{H} 2 \cdots \mathrm{H} 3$ contact from $1.69(2)$ $\AA$ (neutron diffraction) or 1.63(4) $\AA$ (X-ray diffraction) in the neutral complex to an average of $1.36(6) \AA$ (from the X-ray data) in the cation. The difference is significant at the $2 \sigma$ level relative to the X-ray structure, at the $4 \sigma$ level relative to the neutron structure. Unfortunately, suitable crystals of compound $[\mathbf{2 a}]^{+} \mathrm{PF}_{6}{ }^{-}$for a neutron diffraction analysis could not be grown. Even when keeping the uncertainty into account, however, the $\mathrm{H} 2 \cdots \mathrm{H} 3$ separation in the cationic complex falls inside the range of compounds that have previously been described as "stretched" or "elongated" dihydrogen complexes, or alternatively as "compressed" dihydrides. $^{[28,39]}$ Thus, it appears that the oxidation process has increased the interaction between the two hydride ligands $\mathrm{H} 2$ and $\mathrm{H} 3$. 
Compound $[\mathbf{2} \mathbf{a}]^{+} \mathrm{PF}_{6}{ }^{-}$appears to be the first reported paramagnetic polyhydride complex showing evidence for a stretched dihydrogen ligand (or compressed $\mathrm{MH}_{2}$ system). It is interesting to compare this structure with that of the previously published isoelectronic $\left[\mathrm{Cp} * \mathrm{~W}(\mathrm{dppe}) \mathrm{H}_{3}\right]^{+}$complex. The two systems show a very different arrangement of the three hydride ligands, the closest $\mathrm{H} \cdots \mathrm{H}$ contact in the tungsten complex being $2.11 \AA{ }^{[9]}$ Although the $\mathrm{H}$ positions in this tungsten complex should again be considered with caution since this structure was also obtained from X-ray diffraction data, the relative arrangement of the heavy atoms that define the coordination sphere (the $\mathrm{Cp}$ ring, the metal, and the $\mathrm{P}$ donor atoms) is quite different in the two compounds. As we know, the $\mathrm{W}$ complex is stable and has no tendency to decompose, notably by $\mathrm{H}_{2}$ elimination.

The oxidation product obtained from $\mathbf{2} \mathbf{b}$ is rather short-lived at room temperature and could not be isolated. It was only characterized in situ by EPR spectroscopy, see Figure 4. Like $[\mathbf{2 a}]^{+}$, it exhibits a rather broad spectrum at ambient temperature, which become sufficiently resolved at lower temperatures to allow the identification of the expected quartet of triplet feature, consistent with the presence of two phosphorus donor atoms and three hydride ligands, flanked by the ${ }^{95} \mathrm{Mo}$ and ${ }^{98} \mathrm{Mo}$ isotope satellites. This suggests, like for the $1,2,4-t \mathrm{Bu}_{3}$ analogue, that one-electron oxidation has afforded complex $[\mathbf{2 b}]^{+}$.

The spectroscopic properties, however are peculiar in many respects. The simulation on the basis of any combination of spin $1 / 2$ nuclei different than $\mathrm{P}_{2} \mathrm{H}_{3}$ (for instance, $2 \mathrm{P}$ and $2 \mathrm{H}$ ) failed to provide a spectrum sufficiently resembling the experimental one. However, the simulation for the $\mathrm{P}_{2} \mathrm{H}_{3}$ spin system was not nearly as satisfactory as for the [2a] $]^{+}$homologue. An unrestricted full parameter optimization resulted in too broad lateral features and a too sharp central one, compared to the experimental spectrum (Figure 4), for a broadening factor of $2.07 \mathrm{G}$. An artificial reduction of the line broadening parameter to $1.4 \mathrm{G}$ allows a perfect match of the two lateral features of the triplet, but the central feature becomes too sharp 
relative to the experiment. This may indicate a dynamic exchange process on the EPR time scale. Indeed, virtual triplets displaying artificially broadened central features are commonly found in the NMR spectra of diamagnetic compounds featuring suitable site exchange phenomena, such as the $\mathrm{X}$ signal for an $\mathrm{ABX}$ system where sites $\mathrm{A}$ and $\mathrm{B}$ are near the fast exchange limit. ${ }^{[40,41]}$ A rapid hydride scrambling process takes place for [2a] ${ }^{+}$(symmetric $^{2}$ EPR coupling pattern, inequivalent hydride positions by X-ray crystallography), as well as for the neutral precursors (vide supra) and for the related $\left[\mathrm{Cp}^{*} \operatorname{Mo}(\mathrm{dppe}) \mathrm{H}_{3}\right]^{\mathrm{n+}}(\mathrm{n}=0,1)$ complexes. ${ }^{[9]}$ This exchange is possibly slower for the more encumbered $\left(\mathrm{C}_{5} \mathrm{HiPr}_{4}\right)$ derivative, causing the observed lineshape effect. It is interesting to note that the exchange rates are similar for the neutral precursors (slightly smaller for $\mathbf{2 a}$ ), whereas the exchange process appears faster in $\mathbf{2} \mathbf{a}^{+}$than in $\mathbf{2} \mathbf{b}^{+}$.

The next peculiar feature of the EPR spectrum of $[\mathbf{2 b}]^{+}$is a much lower value shown by $a_{\mathrm{P}}$ and $a_{\mathrm{H}}\left(\right.$ namely $\left.a_{\mathrm{P}}=6.2 \mathrm{G} ; a_{\mathrm{H}}=1.7 \mathrm{G} ; a_{\mathrm{Mo}}=29.4 \mathrm{G}\right)$ relative to both $[\mathbf{2 a}]^{+}(\mathrm{ap}=36.2 \mathrm{G}$, $\mathrm{a}_{\mathrm{H}}=11.4 \mathrm{G}$ and $\left.\mathrm{a}_{\mathrm{Mo}}=30.8 \mathrm{G}\right)^{[21]}$ and $\left[\mathrm{Cp} * \mathrm{Mo}(\mathrm{dppe}) \mathrm{H}_{3}\right]^{+}\left(\mathrm{a}_{\mathrm{P}}=29.8 \mathrm{G} ; \mathrm{a}_{\mathrm{H}}=11.8 \mathrm{G}\right) .{ }^{[9]}$ The cause of this phenomenon is not quite clear, but the different coupling values suggest that $[\mathbf{2 b}]^{+}$adopts a different geometry relative to that of $[\mathbf{2 a}]^{+}$, possibly involving the complete collapse of two hydrides to a dihydrogen ligand. It is easy to imagine how the greater bulk of the substituted cyclopentadienyl ring in $[\mathbf{2 b}]^{+}$might force the two $\mathrm{H}$ atoms closer together. This phenomenon may well be related to the slower hydride mutual exchange, as well as to our inability to isolate the compound. Related to this point, we recall that the tetrahydride protonation product is stable in the case of $\mathbf{3 a}$ but decomposes in the case of $\mathbf{3 b}$, although the same system 4a,b is obtained in $\mathrm{MeCN}$. Thus, we speculate that the extreme bulk of the $\mathrm{C}_{5} \mathrm{HiPr} 4$ ligand has the effect of pushing out an $\mathrm{H}_{2}$ ligand from both systems $\mathbf{3 b}$ and $[\mathbf{2 b}]^{+}$. 


\section{(d) Oxidatively induced $\mathrm{H}_{2}$ reductive elimination}

Although compound $[\mathbf{2} \mathbf{a}]^{+} \mathrm{PF}_{6}^{-}$is quite stable as a crystallized solid and in THF solution at low temperatures, it slowly decomposed at $\mathrm{T}>0^{\circ} \mathrm{C}$, as indicated by a color change from orange to green. Well formed green crystals were obtained by slow crystallization from $\mathrm{THF} /$ pentane at $-20^{\circ} \mathrm{C}$. This product appeared thermally stable with no noticeable change over time in the solid state and in THF solution at room temperature. X-ray diffraction analysis revealed the identity of the compound as $\left[\left(1,2,4-\mathrm{C}_{5} \mathrm{H}_{2} t \mathrm{Bu}_{3}\right) \mathrm{MoH}\left(\mathrm{PMe}_{3}\right)_{2}\right]^{+} \mathrm{PF}_{6}, \mathbf{5 a}$. A view of the structure is presented in our previous communication, ${ }^{[21]}$ while selected bonding parameters are reported in Table 1. Therefore, the compound derives from its precursor $[\mathbf{2} \mathbf{a}]^{+} \mathrm{PF}_{6}^{-}$by $\mathrm{H}_{2}$ elimination, see Scheme 4.

$\left[\left(1,2,4-\mathrm{C}_{5} \mathrm{H}_{2} t \mathrm{Bu}_{3}\right) \mathrm{Mo}\left(\mathrm{PMe}_{3}\right)_{2} \mathrm{H}_{3}\right]^{+} \mathrm{PF}_{6}^{-} \stackrel{\mathrm{THF}, \mathrm{O}^{\circ} \mathrm{C}}{-\mathrm{H}_{2}}\left[\left(1,2,4-\mathrm{C}_{5} \mathrm{H}_{2} t \mathrm{Bu}_{3}\right) \mathrm{Mo}\left(\mathrm{PMe}_{3}\right)_{2} \mathrm{H}^{+} \mathrm{PF}_{6}^{-}\right.$

\section{Scheme 4}

Although the quality of the data set allowed the identification of a single hydride ligand with a high level of confidence (see Experimental section), the question of the possible presence of additional hydride ligands in the structure of compound $\mathbf{5 a}$ has been considered carefully, since hydrogen atoms may be difficult to locate from X-ray diffraction data. Possibilities include the presence of one, two or three additional hydride ligands, giving a 16electron dihydride, a 17-electron trihydride (a stereoisomer of the precursor $[\mathbf{2 a}]^{+}$), and an 18 electron tetrahydride cation (i.e. complex 3a), as well as a dihydrogen ligand, yielding a nonclassical tautomer of $[\mathbf{2 a}]^{+}$. The color of $\mathbf{5 a}$ relative to $[\mathbf{2 a}]^{+} \mathrm{PF}_{6}{ }^{-}$excludes an isomeric form of $[\mathbf{2 a}]^{+}$and also the tetrahydride formulation, although the bond distances and angles related to the heavy atoms in the cation of $\mathbf{5 a}$, see Table 1, are not too different from those observed for compound $\mathbf{3 a}$. 
The ${ }^{1} \mathrm{H}$ NMR spectrum of the isolated solid only revealed the resonances of the tetrahydride complex 3a, indicating that this compound is a decomposition by-product (the solid was a mixture of well formed crystals and a powder). Complex 3a certainly arises from the transfer of a proton from acidic $[\mathbf{2 a}]^{+}$to residual $\mathbf{2 a}$, similarly to what occurs for the $\mathrm{Cp} * \mathrm{Mo}(\mathrm{dppe}) \mathrm{H}_{3}$ analogue. ${ }^{[16]}$ A solid sample of the isolated compound showed bulk paramagnetism, however a reliable value for the magnetic moment could not be obtained, given the impure nature of the sample. ${ }^{1} \mathrm{H}$ NMR monitoring of the decomposition reaction also showed the formation of $\mathbf{3 a}$, in addition to the formation of $\mathrm{H}_{2}$.

Positive identification of the green decomposition product as a 15-electron species comes from EPR spectroscopy. As detailed in the communication, ${ }^{[21]}$ the solid sample shows features consistent with a spin quartet ground state at the liquid He temperature (Figure 5a): $g_{x}$ and $g_{y}$ at 3.74 and $3.45\left( \pm 1 / 2\right.$ transition), plus a weak feature $\left(g_{z}\right.$ for the forbidden $\pm 3 / 2$ transition) at 5.33. The $\mathrm{g}=3.74$ peak appears to display a fine structure, possibly due to coupling to the two equivalent $P$ nuclei. The $g_{z}$ component of the $\pm 1 / 2$ transition is not visible because it is overshadowed by stronger resonances in the $g=2$ region (shown in Figure $5 b$ ). The resonance observed at $\mathrm{g}=2.009$ for the polycrystalline sample is very close to the position observed at higher temperature for the precursor complex [2a] ${ }^{+}$and is therefore attributed to a residual amount of this material, which had co-crystallized with the $\mathrm{H}_{2}$ elimination product 5a (see Experimental section). 

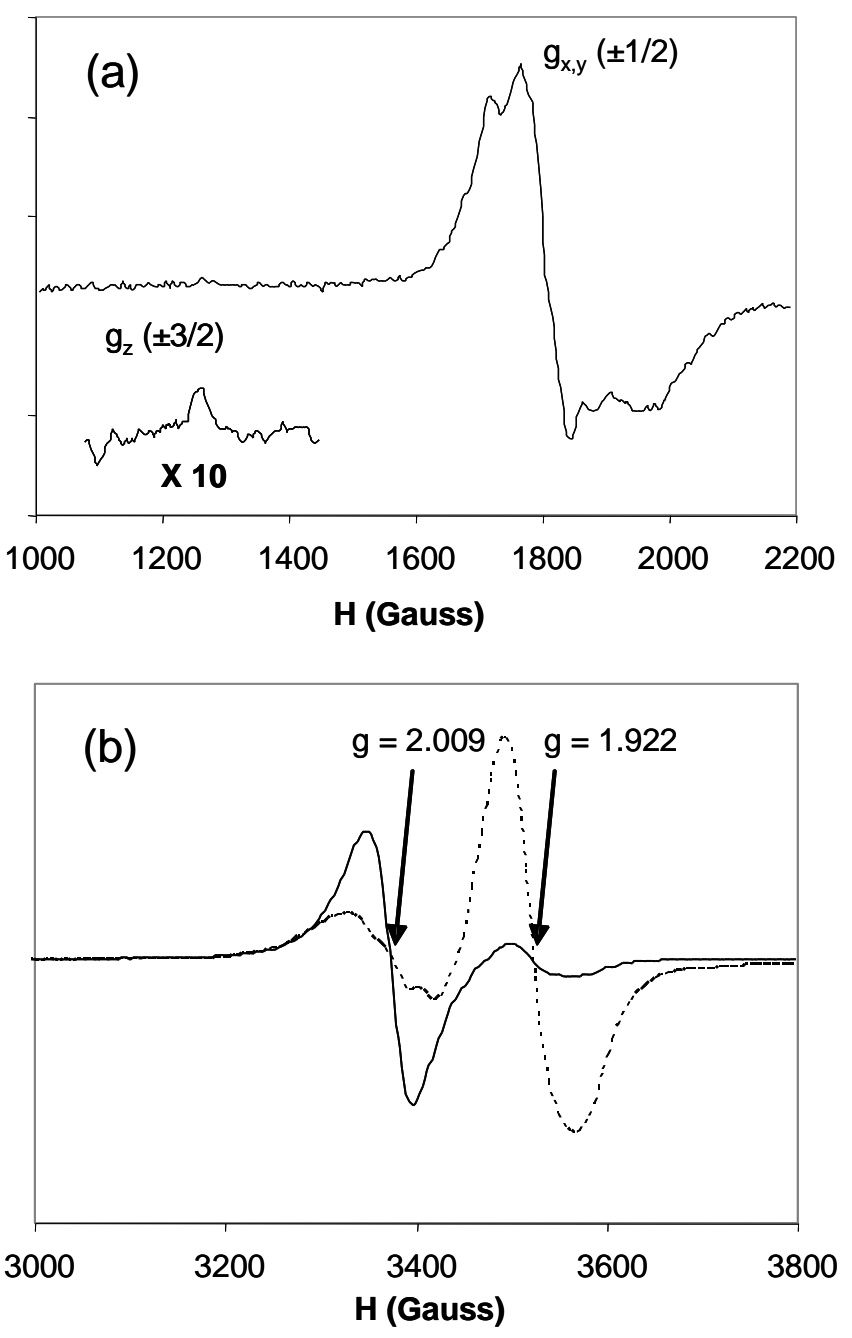

Figure 5. Liquid He EPR spectrum of compound 5a: (a) polycrystalline sample in the $g=4$ 6 region; (b) polycrystalline sample (solid line) and frozen THF glass (dashed line) in the $\mathrm{g}=2$ region.

Solutions of compound 5a in THF were EPR silent at room temperature and showed only a weak resonance at the liquid nitrogen temperature. On the other hand, they show an intense band at $\mathrm{g}=1.922$ at the liquid He temperature. The two resonances at $\mathrm{g}=2.009$ and 1.922 are visible for both polycrystalline and THF solution samples, but their relative intensity is opposite. The latter must belong to another $S=1 / 2$ complex and we therefore assign it to the THF adduct, $\left[\left(1,2,4-\mathrm{C}_{5} \mathrm{H}_{2} t \mathrm{Bu}_{3}\right) \mathrm{Mo}\left(\mathrm{PMe}_{3}\right)_{2}(\mathrm{THF}) \mathrm{H}\right]^{+}$. Its presence for the polycrystalline sample, which had been obtained by crystallization from THF (see Experimental section), represents evidence of solution equilibrium between the solvent-free, 
15-electron, spin quartet monohydride complex and a spin doublet solvent adduct. The compound crystallizes preferentially in the solvent-free form, but the THF adduct also appears to exist in the solid state. Additional evidence for this equilibrium will be provided by the electrochemical analysis (vide infra).

As stated in the Introduction, we previously reported the first unambiguous oxidative induced reductive elimination of $\mathrm{H}_{2}$ from the one-electron oxidation of complex $\mathrm{Cp}^{*} \mathrm{Mo}(\mathrm{dppe}) \mathrm{H}_{3}$. However, the elimination product could not be crystallized and was only characterized in solution as the 17 -electron solvent adduct $\left[\mathrm{Cp}^{*} \mathrm{Mo}(\mathrm{dppe})(\mathrm{solv}) \mathrm{H}\right]^{+}$by EPR spectroscopy $\left(\text { solv }=\mathrm{THF}, \mathrm{CH}_{2} \mathrm{Cl}_{2}\right)^{[9]}$ and by electrochemistry $($ solv $=\mathrm{MeCN}) .{ }^{[16]}$ The steric bulk of the $\mathrm{PMe}_{3}$ and $1,2,4-\mathrm{C}_{5} \mathrm{H}_{2} t \mathrm{Bu}_{3}$ ligands, in combination with the electron pairing stabilization provided by the spin quartet state, ${ }^{[42,43]}$ accounts for the absence of solvent coordination to complex 5a. The oxidatively induced reductive elimination of compounds containing two one-electron ligands $\{\mathrm{M}(\mathrm{X})(\mathrm{Y})$, leading to the elimination of $\mathrm{X}-\mathrm{Y}\}$ has previously been demonstrated for dialkyl complexes $\left\{M(R)_{2}\right\}$ to give the alkane coupling product $\mathrm{R}-\mathrm{R}^{[18,44-50]}$ and for alkyl-hydride complexes $\{\mathrm{M}(\mathrm{R})(\mathrm{H})\}$ to give the corresponding alkane $\mathrm{R}-\mathrm{H},{ }^{[18,47]}$ plus products originating from $\{\mathrm{M}\}^{+}$. To the best of our knowledge, the 15electron $\{\mathrm{M}\}^{+}$product was not isolated and characterized in any of those studies. For $\mathrm{X}=\mathrm{Y}$ $=\mathrm{H}$, as stated in the Introduction, oxidation often results in dihydrogen evolution but the multitude of decomposition pathways of the intermediate oxidized polyhydride complexes often obscure the clean identification of the oxidatively induced reductive elimination pathway. Therefore, the present investigation illustrates the first well defined example of an oxidatively induced reductive elimination of $\mathrm{H}_{2}$, through the full characterization of starting and end product of the $\mathrm{H}_{2}$ elimination process.

Since the greater bulk of the $\mathrm{C}_{5} \mathrm{H}_{2} \mathrm{Pr}_{4}$ ring should cause an even more favorable $\mathrm{H}_{2}$ elimination process, the decomposition of the less thermally stable $[\mathbf{2 b}]^{+}$would be expected to 
lead to another 15-electron monohydride species, $\mathbf{5 b}$, analogous to $\mathbf{5 a}$. Upon warming to room temperature, orange solutions of $[\mathbf{2 b}]^{+}$change color to blue, but the transformation is accompanied by the development of new EPR signals indicative of other $S=1 / 2$ species, which replaced the signal of the cationic trihydride complex. Thus, this decomposition is less well behaved than that of $[\mathbf{2 a}]^{+}$, which led to an EPR silent solution (at room temperature). We cannot exclude the presence of species $\mathbf{5 b}$ in this solution, but attempts to crystallize one or more of the decomposition products from this solution were unsuccessful.

\section{(e) Electrochemical studies}

Both compounds 2 exhibit a reversible one-electron oxidation in both THF and $\mathrm{MeCN}$ at the usual scan rates. The measured $\mathrm{E}_{1 / 2}$ values for $\mathbf{2 a}$ and $\mathbf{2} \mathbf{b}$ are very similar (2a: $-0.93 \mathbf{V}$ in $\mathrm{MeCN},-0.89 \mathrm{~V}$ in THF; $2 \mathbf{b}:-0.95 \mathrm{~V}$ in $\mathrm{MeCN},-0.88$ in THF vs. the ferrocene standard). These potentials are slightly more negative than those measured for the related $\mathrm{Cp}^{*} \mathrm{Mo}(\mathrm{dppe}) \mathrm{H}_{3}$ compound $(-0.85 \mathrm{~V} \text { in } \mathrm{MeCN} \text { and }-0.73 \mathrm{~V} \text { in } \mathrm{THF})^{[9]}$ in agreement with the greater electron donating power of the coordination sphere. While the process is reversible in THF for scan rates as low as $10 \mathrm{mV} \mathrm{s}^{-1}$ for both compounds, the back reduction wave loses intensity relative to the oxidation wave at slow scan rates in $\mathrm{MeCN}$. A figure is provided in the Supporting Information.

The cyclic voltammetry of compounds $\mathbf{2 a}$ and $\mathbf{2 b}$ has been investigated in $\mathrm{MeCN}$ and THF at variable scan rates and different potential ranges. The observed behavior is closely related to that of complex $\mathrm{Cp} * \mathrm{Mo}(\mathrm{dppe}) \mathrm{H}_{3},{ }^{[9,16]}$ a detailed study of which revealed three simultaneous decomposition pathways for the one-electron oxidation product, $\left[\mathrm{Cp} * \mathrm{Mo}(\text { dppe }) \mathrm{H}_{3}\right]^{+}$: deprotonation, disproportionation and $\mathrm{H}_{2}$ elimination. Each pathway could be independently quantified (e.g. $k_{\text {deprot }}=2.8(2) \cdot 10^{2} \mathrm{~s}^{-1} \mathrm{M}^{-1}, k_{d i s p}=3.98(9) \cdot 10^{3} \mathrm{~s}^{-1} \mathrm{M}^{-1}$ and $k_{\text {elim }}=2.0(4) \cdot 10^{-2} \mathrm{~s}^{-1} \mathrm{M}^{-1}$ in $\left.\mathrm{MeCN}\right) .{ }^{[9,16]}$ For complexes $\mathbf{2 a}$ and $\mathbf{2 b}$, we did not carry out a 
thorough quantitative study. Rather, we focused only the voltammetric features that could provide additional information about the $\mathrm{H}_{2}$ elimination pathway.

All three decomposition pathways of $\left[\mathrm{Cp}^{*} \mathrm{Mo}(\mathrm{dppe}) \mathrm{H}_{3}\right]^{+}$have an associative character: disproportionation is initiated by solvent coordination to the 17-electron $\left[\mathrm{Cp} * \mathrm{Mo}(\mathrm{dppe}) \mathrm{H}\left(\mathrm{H}_{2}\right)\right]^{+}$isomer; deprotonation needs the involvement of a molecule of neutral, 18-electron $\mathrm{Cp}^{*} \mathrm{Mo}(\mathrm{dppe}) \mathrm{H}_{3}$; and $\mathrm{H}_{2}$ elimination follows initial $\mathrm{MeCN}$ coordination. ${ }^{[16]}$ Indeed, the $\mathrm{H}_{2}$ elimination is much slower in THF $\left(k_{\text {elim }}=2.2(2) \cdot 10^{-5} \mathrm{~s}^{-1} \mathrm{M}^{-1}\right.$; measured independently by decay of the EPR signal), ${ }^{[9]}$ with no visible consequence on the cyclic voltammetric behavior in this solvent. Since compounds $\mathbf{2 a}$ and $\mathbf{2 b}$ have a more crowded coordination sphere than $\mathrm{Cp}^{*} \mathrm{Mo}(\mathrm{dppe}) \mathrm{H}_{3}$, the above three pathways should be slower. However, whereas both disproportionation and deprotonation pathways demand a rate determining associative step, the $\mathrm{H}_{2}$ elimination may also occur dissociatively, in which case the greater ligand steric pressure should accelerate it. We remind here that compound 5a is the stable product of $\mathrm{H}_{2}$ dissociation from [2a] $]^{+}$, although equilibrium amounts of the solvent adduct are present in THF (see EPR characterization above). This suggests a dissociative $\mathrm{H}_{2}$ elimination process in THF but does not exclude an associative process in $\mathrm{MeCN}$.

A two-scan cyclic voltammogram of $\mathbf{2 a}$ at a scan rate of $5 \mathrm{~V} \mathrm{~s}^{-1}$ is shown in Figure 6. When the scan is reversed at $0.7 \mathrm{~V}$ (vs. the reference $\mathrm{Ag} / \mathrm{AgCl}$ electron, i.e. $0.27 \mathrm{~V}$ vs. ferrocene), only an additional oxidation peak $\mathbf{B}$ at $-0.10 \mathrm{~V}(-0.05 \mathrm{~V}$ for $\mathbf{2 b})$ is observed in the voltammogram, in addition to the reversible one-electron oxidation of $\mathbf{2 a}$ at $\mathbf{A} / \mathbf{A}^{\prime}$. There is no return wave associated to this peak, indicating that the generated species decomposes rapidly. Note that the voltammogram does not change significantly in the second scan. When the potential sweep is switched at a higher potential, on the other hand, a third oxidation process D, also irreversible, appears at ca. $0.8 \mathrm{~V}$. Following the first potential sweep reversal, a new reversible process at $\mathbf{C} / \mathbf{C}^{\prime}$ becomes visible at $\mathrm{E}_{1 / 2}=-0.15 \mathrm{~V}(-0.10 \mathrm{~V}$ for $\mathbf{2 b})$. Oxidation peak 
$\mathbf{C}$ overlaps with peak $\mathbf{B}$ in the second scan. The behavior of compound $\mathbf{2} \mathbf{b}$ is very similar to that of $\mathbf{2 a}$. The $\mathbf{C} / \mathbf{C}^{\prime}$ process shows a reduced reversibility for compound $\mathbf{2} \mathbf{b}$. Voltammograms of $\mathbf{2 a}$ and $\mathbf{2} \mathbf{b}$ at variable scan rates are available in the Supporting Information.

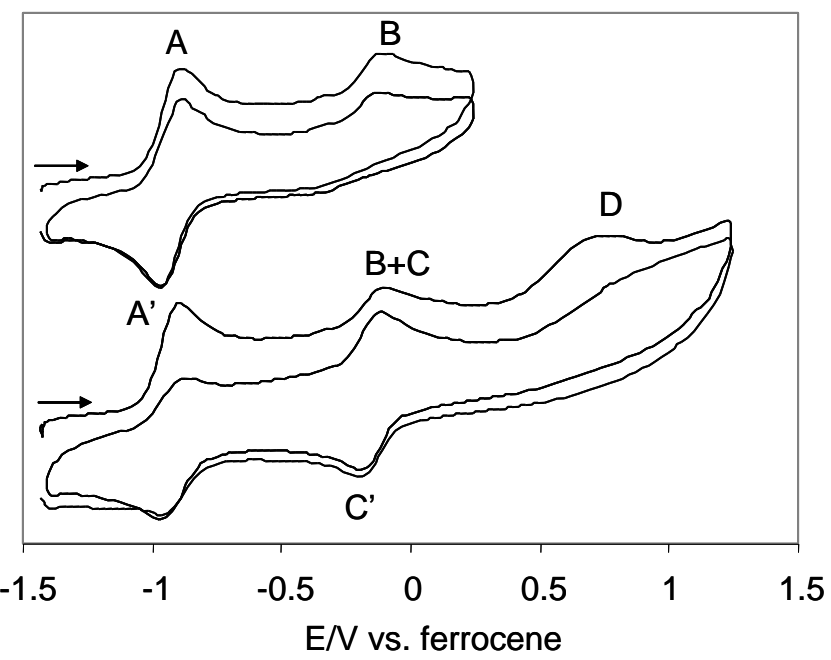

Figure 6. Two-scan cyclic voltammograms of compound 2a in MeCN. Scan rate $=5000$ $\mathrm{mV} \mathrm{s}^{-1}$.

According to the previous study, the above observations are interpreted as follows, see

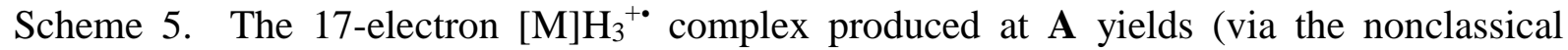
isomer $\left.[\mathrm{M}] \mathrm{H}\left(\mathrm{H}_{2}\right)^{+\bullet}\right)$ complex $[\mathrm{M}] \mathrm{H}(\mathrm{MeCN})^{+\bullet}$, which is responsible for the oxidation peak $\mathbf{B}$. The complete lack of reversibility for the latter is due to the immediate saturation by solvent coordination, to afford the 18 -electron $[\mathrm{M}] \mathrm{H}(\mathrm{MeCN})_{2}{ }^{2+}$. On the other hand, subsequent oxidation of $[\mathrm{M}] \mathrm{H}_{3}{ }^{+\bullet}$ at $\mathbf{D}$ leads to the 16 -electron $[\mathrm{M}] \mathrm{H}_{3}{ }^{2+}$, which is immediately followed by

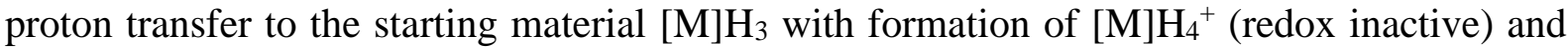
$[\mathrm{M}] \mathrm{H}_{2}(\mathrm{MeCN})^{+}$. The latter is responsible for the reversible process $\mathbf{C} / \mathbf{C}^{\prime}$. A deeper analysis of these processes and complimentary investigations confirming their assignment were carried out during the previous study. ${ }^{[16]}$ The two anodic waves of peaks $\mathbf{B}$ and $\mathbf{C}$ accidentally overlap for $[\mathrm{M}]=\left(1,2,4-\mathrm{C}_{5} \mathrm{H}_{2} t \mathrm{Bu}_{3}\right) \mathrm{Mo}\left(\mathrm{PMe}_{3}\right)_{2}$, whereas they differ only slightly for $[\mathrm{M}]=$ Cp*Mo(dppe) $(\Delta \mathrm{E}=0.14 \mathrm{~V}) .{ }^{[16]}$ The essentially identical potentials measured for 17-electron 
$[\mathrm{M}] \mathrm{H}(\mathrm{MeCN})^{+\bullet}$ and 18-electron $[\mathrm{M}] \mathrm{H}_{2}(\mathrm{MeCN})^{+}$agree with a high covalent nature for the Mo-H bond.

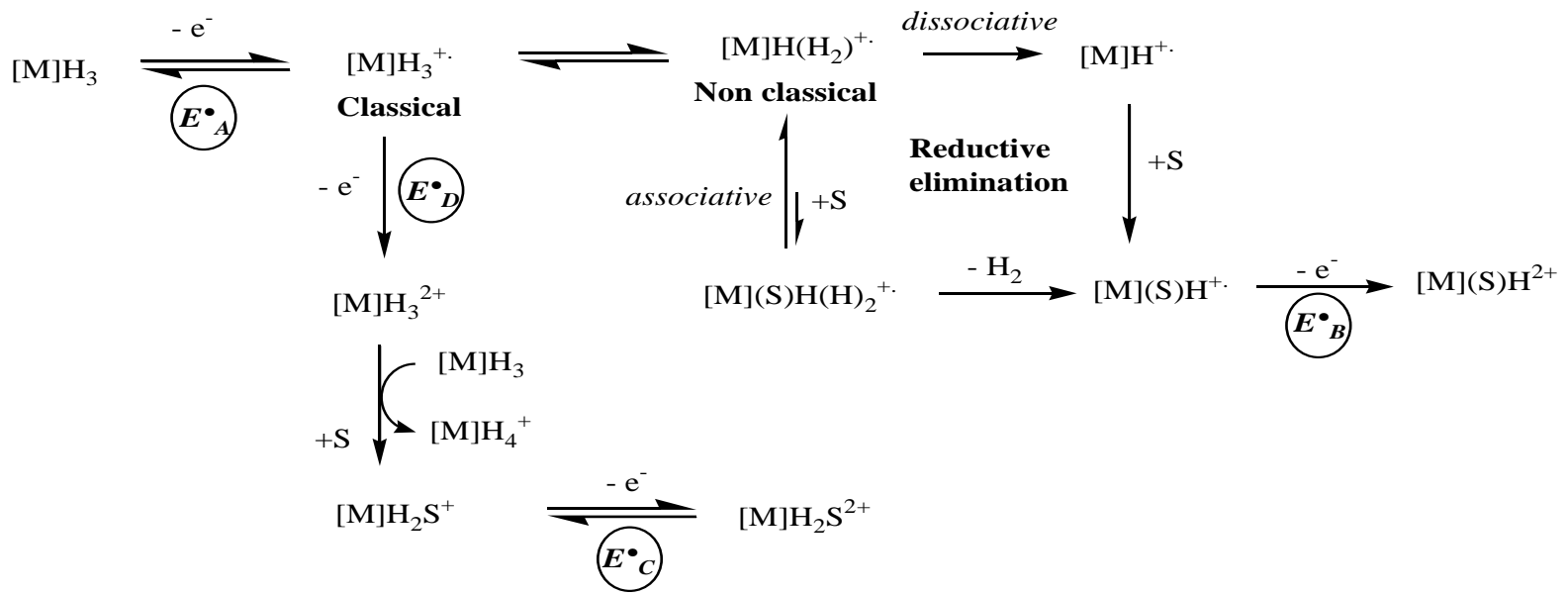

\section{Scheme 5}

The essential point is that peak $\mathbf{B}$ is observed even at the highest scan speeds (up to $5 \mathrm{~V}$ $\mathrm{s}^{-1}$ ), whereas the same process for system $\mathrm{Cp} * \mathrm{Mo}(\mathrm{dppe}) \mathrm{H}_{3}$ became observable only at $\mathrm{v}<0.6$ $\mathrm{V} \mathrm{s}^{-1}$ in neat $\mathrm{MeCN}$. This illustrates that the $\mathrm{H}_{2}$ elimination process is fast for systems [2a $]^{+}$ and $[\mathbf{2 b}]^{+}$, faster than when $[\mathrm{M}]=\mathrm{Cp} * \mathrm{Mo}(\mathrm{dppe})$, thus strongly suggesting that it proceeds dissociatively.

The voltammograms of $\mathbf{2 a}$ in THF, see Figure 7, show many similarities but also interesting differences with respect to the behavior of the same compound in $\mathrm{MeCN}$ and to that of compound $\mathrm{Cp} * \mathrm{Mo}(\mathrm{dppe}) \mathrm{H}_{3}$ in THF. Following the oxidation at $\mathbf{A}$, the irreversible peak $\mathbf{B}$ and the second oxidation process $\mathbf{D}$ are observed like in $\mathrm{MeCN}$. Transit over process D does not generate a reversible $\mathbf{C} / \mathbf{C}^{\prime}$ couple. Transit over process $\mathbf{B}$, on the other hand, generates a weak and broad reduction peak $\mathbf{E}$ at ca. $-1.9 \mathrm{~V}$, while peak $\mathbf{A}$ loses reversibility. A full rationalization of all these observations is not possible, as many of the species 
implicated in Scheme 5 may be unstable and evolve to other unknown products when $\mathrm{S}=$ THF. Whereas the potentials of peaks $\mathbf{A}$ and $\mathbf{D}$ are close to the values observed in $\mathrm{MeCN}$, peak $\mathbf{B}$ occurs at $\mathrm{E}_{\mathrm{p}, \mathrm{a}}$ ca. $0.25 \mathrm{~V}$ in THF ( $v s .-0.18 \mathrm{~V}$ in $\mathrm{MeCN}$ ). The more positive potential in THF may be related to a reduced donating power of THF relative to $\mathrm{MeCN}$ and/or to a more extensive solvent dissociation equilibrium established by the THF adduct with the 15electron complex. Indeed, the presence of this equilibrium has been evidenced by the EPR study (see above). The most interesting feature, however, is the fact that compound 2a shows peak $\mathbf{B}$ also in THF, whereas compound $\mathrm{Cp} * \mathrm{Mo}(\mathrm{dppe}) \mathrm{H}_{3}$ only shows it in $\mathrm{MeCN} .^{[16]}$ This is consistent with a dissociative mechanism for the $\mathrm{H}_{2}$ substitution in $[\mathbf{2 a}]^{+}$, in which case the rate should be essentially solvent independent. Indeed, peak $\mathbf{B}$ is observable in THF even at the fast scan rates $\left(1 \mathrm{~V} \mathrm{~s}^{-1}\right)$.

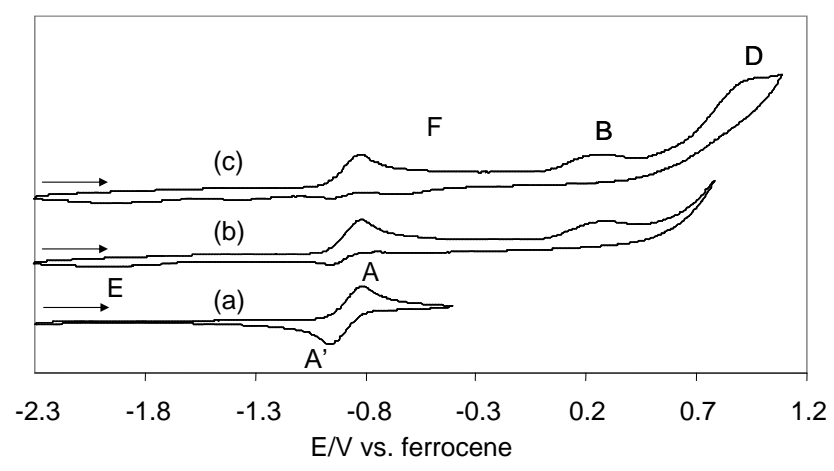

Figure 7. Cyclic voltammograms of compound 2a in THF with different switching potentials. Scan rate $=200 \mathrm{mV} \mathrm{s}^{-1}$.

The behavior of $\mathbf{2} \mathbf{b}$ in THF shows similarities to that of $\mathbf{2 a}$ (see figure in the Supporting Information). Notably, a peak corresponding to process $\mathbf{B}$ is again present ( $\mathrm{E}_{\mathrm{p}, \mathrm{a}}=0.2 \mathrm{~V}$ vs. ferrocene). The behavior at higher potential, however, is more complex and not fully understood. It is possible that only a fraction of $[\mathbf{2 b}]^{+}$undergoes $\mathrm{H}_{2}$ elimination, in competition with other decomposition processes, in the THF solvent. This seems to be suggested also by the EPR monitoring of this decomposition (vide supra). It seems clear, 
however, that the first decomposition mode $\left(\mathrm{H}_{2}\right.$ elimination to afford a 15-electron derivative, possibly in equilibrium with a 17-electron THF adduct) is also established by this system.

\section{Conclusion}

We have shown that the combination of greater ligand donor power and greater steric bulk in the coordination sphere of half sandwich $\mathrm{Mo}^{\mathrm{IV}}$ trihydride complexes stabilizes the 17electron products of one-electron oxidation. Complex $\left[\left(1,2,4-\mathrm{C}_{5} \mathrm{H}_{2} t \mathrm{Bu}_{3}\right) \mathrm{Mo}\left(\mathrm{PMe}_{3}\right)_{2} \mathrm{H}_{3}\right]^{+}$is sufficiently stable to be crystallized and structurally characterized. Its geometry is very close to that of the neutral precursor, except that the separation between two hydride ligands is shorter suggesting the presence of a stretched dihydrogen ligand (or compressed $\mathrm{MH}_{2}$ moiety). To the best of our knowledge, this is the first time that such evidence has been obtained for a paramagnetic polyhydride system. The steric control in this system, however, is rather subtle: on going from the $1,2,4-\mathrm{C}_{5} \mathrm{H}_{2} t \mathrm{Bu}$ system to the more encumbered $\mathrm{C}_{5} \mathrm{H} i \operatorname{Pr}_{4}$ system, the paramagnetic trihydride product becomes less stable and could not be isolated. The $\mathrm{C}_{5} \mathrm{HiPr}_{4}$ ligand might impose such steric pressure to the $\mathrm{MoH}_{3}$ system as to force a stronger interaction between two hydride ligands and a more favorable expulsion of $\mathrm{H}_{2}$. This also appears true for the tetrahydrido protonation product (3a vs. 3b). A peculiar difference between the ground state properties of $[\mathbf{2 a}]^{+}$and $[\mathbf{2 b}]^{+}$has been evidenced by EPR spectroscopy (Figure 4). The present investigation has also revealed a dissociative pathway for $\mathrm{H}_{2}$ substitution by a solvent molecule in the paramagnetic system. The oxidative behavior of the half-sandwich Mo trihydride system is summarized in Scheme 6: $\mathrm{H}_{2}$ substitution by $\mathrm{MeCN}$ on $\left[\mathrm{Mo}_{\mathrm{H}_{3}}{ }^{+}\right.$is associative for $[\mathrm{Mo}]=\mathrm{Cp}^{*} \mathrm{Mo}(\mathrm{dppe})$ and dissociative for $\mathrm{Cp}^{\#} \mathrm{Mo}\left(\mathrm{PMe}_{3}\right)_{2}$; an equilibrium has been established by EPR spectroscopy for the latter system between the 15-electron species (complex 5a) and its solvent adduct in THF, whereas 
no evidence was previously obtained for a 15 -electron species in the $\mathrm{Cp}^{*} \mathrm{Mo}(\mathrm{dppe})$ case. The dissociative product has in fact been isolated and structurally characterized, providing the first well characterized example of an oxidatively induced reductive elimination of $\mathrm{H}_{2}$ from a polyhydride compound.

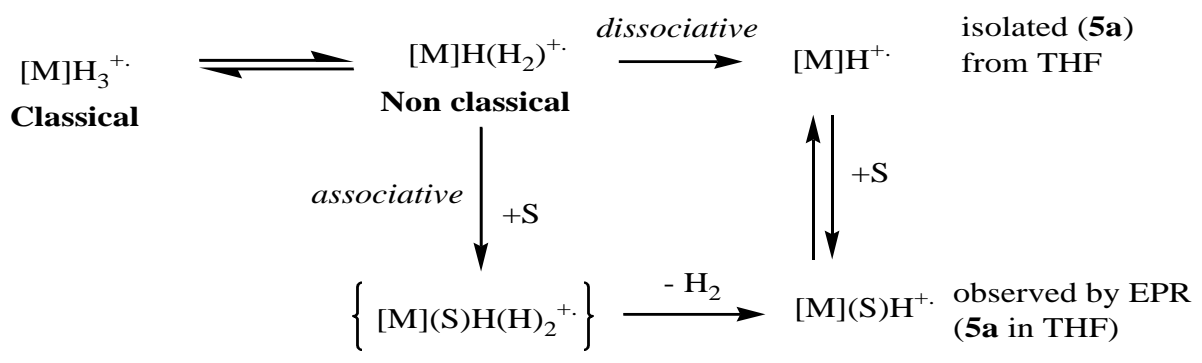

\section{Scheme 6}

\section{Experimental Section}

General procedures. All operations were carried out under an atmosphere of argon using standard Schlenk line and glove box techniques. Solvents were dehydrated $\left(\mathrm{CH}_{2} \mathrm{Cl}_{2}\right.$ : $\mathrm{CaH}_{2}$; THF, toluene, sodium benzophenone ketyl) and distilled under dinitrogen prior to use. $\mathrm{Mo}(\mathrm{CO})_{6}$ and $\mathrm{PMe}_{3}(1 \mathrm{M}$ solution in THF) were purchased from Aldrich and used as received. Compounds 1,2,4-tri(tert-butyl)- and tetra(iso-propyl)-cyclopentadiene (as isomer mixtures) were prepared by literature methods ${ }^{[51,52]}$ and converted to their corresponding sodium salts by reaction with $\mathrm{NaNH}_{2}$.

(b) Measurements. NMR measurements were carried out on either a Bruker AC 200 or a Bruker AMX250 spectrometer and calibrated with the residual solvent resonances $\left({ }^{1} \mathrm{H}\right)$ or with external $85 \% \mathrm{H}_{3} \mathrm{PO}_{4}\left({ }^{31} \mathrm{P}\right)$. The lineshape analyses for the dynamic processes were carried out by simulation with DNMR3, which is incorporated into the freely available SpinWorks program. ${ }^{[53]}$ EPR spectra were measured on a Elexsys E500 BRUKER 
spectrometer equipped with both a frequencymeter and gaussmeter. The spectrometer frequency was calibrated with diphenylpicrylhydrazyl $(\mathrm{DPPH}, \mathrm{g}=2.0037) . \quad$ EPR spectra simulations and fittings were carried out with the freely available WinSim program. ${ }^{[54]}$ Cyclic voltammograms were recorded with an EG\&G 362 potentiostat connected to a Macintosh computer through MacLab hardware/software. The electrochemical cell was fitted with an $\mathrm{Ag}-\mathrm{AgCl}$ reference electrode, a platinum disk working electrode and a platinum wire counterelectrode. $\left[\mathrm{Bu}_{4} \mathrm{~N}\right] \mathrm{PF}_{6}(\mathrm{ca} .0 .1 \mathrm{M})$ was used as supporting electrolyte. The ferrocene standard had a potential of $0.43 \mathrm{~V}$ in $\mathrm{MeCN}$ and $0.62 \mathrm{~V}$ in THF under our experimental conditions.

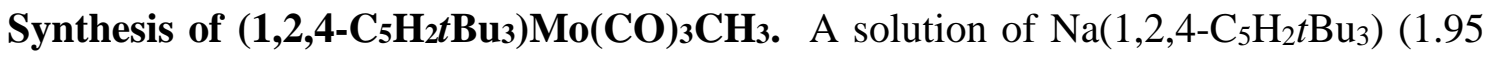
$\mathrm{g}, 8.3 \mathrm{mmol})$ in THF $(20 \mathrm{~mL})$ was transferred into a suspension of $\mathrm{Mo}(\mathrm{CO})_{6}(2.20 \mathrm{~g}, 8.3$ mmol) in THF (15 mL). The mixture was heated to reflux for $15 \mathrm{~h}$, during which time a colour change from pale yellow to dark red was observed. The mixture was then cooled and $\mathrm{CH}_{3} \mathrm{I}$ (1 mL,16 mmol) was added via syringe, causing an immediate colour change to bright yellow. Subsequently, the mixture was heated to reflux for $2 \mathrm{~h}$; following which it was cooled and the solvents evaporated. The residue was then extracted with pentane $(100 \mathrm{~mL})$ and the pentane solution evaporated to yield $\left(1,2,4-\mathrm{C}_{5} \mathrm{H}_{2} t \mathrm{Bu}_{3}\right) \mathrm{Mo}(\mathrm{CO})_{3} \mathrm{CH}_{3}$ as a yellow solid. Yield $=2.642 \mathrm{~g} ; 74 \%$. IR $\left(\mathrm{CH}_{2} \mathrm{Cl}_{2}\right): 2005,1918 \mathrm{~cm}^{-1}\left(v_{\mathrm{CO}}\right)$.

Synthesis of $\left(\mathbf{C}_{5} \mathbf{H i P r}_{4}\right) \mathbf{M o}(\mathbf{C O})_{3} \mathbf{C H}_{3}$. A solution of $\mathrm{Na}\left(\mathrm{C}_{5} \mathrm{Hi}_{i} \mathrm{Pr}_{4}\right)(2.82 \mathrm{~g}, 11.0 \mathrm{mmol})$ in THF $(25 \mathrm{~mL})$ was transferred into a suspension of $\mathrm{Mo}(\mathrm{CO})_{6}(2.88 \mathrm{~g}, 10.9 \mathrm{mmol})$ in $\mathrm{THF}$ (20 $\mathrm{mL}$ ). The mixture was heated to reflux for $16 \mathrm{~h}$, during which time a colour change from pale yellow to dark red was observed. The mixture was then cooled and $\mathrm{CH}_{3} \mathrm{I}(1.5 \mathrm{~mL}, 24$ mmol) was added via syringe, causing an immediate colour change to bright yellow. Subsequently, the mixture was heated to reflux for $2 \mathrm{~h}$; following which it was cooled and the solvents evaporated. The residue was then extracted with pentane and the pentane solution evaporated to yield $\left(1,2,4-\mathrm{C}_{5} \mathrm{H}_{2} t \mathrm{Bu}_{3}\right) \mathrm{Mo}(\mathrm{CO})_{3} \mathrm{CH}_{3}$ as a yellow solid. Yield $=3.739 \mathrm{~g} ; 80 \%$. 
The compound was used directly for the synthesis of $\left(\mathrm{C}_{5} \mathrm{HiPr}_{4}\right) \mathrm{MoCl}_{4}$ (see below), without characterisation.

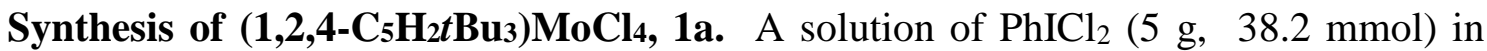
dichloromethane $(20 \mathrm{~mL})$ was transferred slowly into a solution of $(1,2,4-$ $\left.\mathrm{C}_{5} \mathrm{H}_{2} t \mathrm{Bu}_{3}\right) \mathrm{Mo}(\mathrm{CO})_{3} \mathrm{CH}_{3}(2.64 \mathrm{~g}, 6.2 \mathrm{mmol})$ in dichloromethane $(15 \mathrm{~mL})$. The mixture was heated to reflux for $3 \mathrm{~h}$ during which time a colour change from brown to indigo was observed. Solvents were then concentrated to ca. $3 \mathrm{~mL}$ and the resulting suspension was filtered to give a purple solid, which was washed with portions of pentane $(5 \times 50 \mathrm{~mL})$ and then dried under reduced pressure to give $\left(1,2,4-\mathrm{C}_{5} \mathrm{H}_{2} t \mathrm{Bu}_{3}\right) \mathrm{MoCl}_{4}, \mathbf{1 a}$, as a purple solid. Yield $=2.32 \mathrm{~g}, 79 \% . \mathrm{EPR}: \mathrm{g}=1.992, \mathrm{a}_{\mathrm{Mo}}=38.8 \mathrm{G}$.

Synthesis of $\left(\mathbf{C}_{5} \mathrm{HiPr}_{4}\right) \mathrm{MoCl} 4, \mathbf{1 b} . \mathrm{PhICl}_{2}(6.87 \mathrm{~g}, 52.50 \mathrm{mmol})$ dissolved in dichloromethane $(20 \mathrm{~mL})$ was added dropwise to a solution of $\left(\mathrm{C}_{5} \mathrm{Hi} \mathrm{Pr}_{4}\right) \mathrm{MoCO}_{3} \mathrm{CH}_{3}(6.85 \mathrm{~g}$, $15.98 \mathrm{mmol})$ in dichloromethane $(20 \mathrm{~mL})$. The solution was heated to reflux for $3 \mathrm{~h}$, during which time a colour change from brown to indigo was observed. Solvents were then concentrated to ca. $4 \mathrm{~mL}$ and the resulting suspension was filtered. The solid was washed with portions of pentane $(5 \times 20 \mathrm{~mL})$ and dried under reduced pressure to give $\left(\mathrm{C}_{5} \mathrm{HiPr}_{4}\right) \mathrm{MoCl}_{4}, \mathbf{1 b}$, as an indigo solid. Yield $=5.27 \mathrm{~g}, 70 \%$.

Synthesis of (1,2,4-C5 $\left.\mathrm{H}_{2} t \mathrm{Bu}\right) \mathrm{Mo}\left(\mathrm{PMe}_{2}\right)_{2} \mathrm{H}_{3}$, 2a. Compound 1a (1415 mg, $\left.3.00 \mathrm{mmol}\right)$ was dissolved in tetrahydrofuran $(20 \mathrm{~mL})$ and a solution of trimethylphosphine in tetrahydrofuran $(1 \mathrm{M}, 8 \mathrm{~mL}, 8 \mathrm{mmol})$ was added. The mixture was stirred for $30 \mathrm{~min}$, and then a suspension of lithium tetrahydroaluminate $(c a .650 \mathrm{mg})$ in tetrahydrofuran $(40 \mathrm{~mL})$ was carefully added. Gas evolution was observed during the addition. The mixture was stirred for $5 \mathrm{~h}$ then methanol $(c a .6 \mathrm{~mL})$ was added dropwise causing vigorous gas evolution. The resulting suspension was stirred for $1 \mathrm{~h}$ and vacuum-dried; the residue was then extracted with diethyl ether (ca. $150 \mathrm{~mL})$ and filtered through Celite 545. The final solution was vacuum- 
dried, and the residue washed three times with methanol $(6,4$ and $4 \mathrm{~mL})$ and dried in vacuo. The product $2 \mathbf{a}$ was obtained as a pale yellow solid. Yield: $727 \mathrm{mg}(50 \%)$. Anal. Calcd. for $\mathrm{C}_{23} \mathrm{H}_{50} \mathrm{MoP}_{2}: \mathrm{C}, 57.01 ; \mathrm{H}, 10.40$. Found: $\mathrm{C}, 56.48 ; \mathrm{H}, 10.88 .{ }^{1} \mathrm{H}$ NMR $\left(\mathrm{C}_{6} \mathrm{D}_{6}\right): \delta-5.20(\mathrm{t}, J=$ $51.0 \mathrm{~Hz}, 3 \mathrm{H}, \mathrm{Mo}-H), 1.37\left(\mathrm{~s}, 9 \mathrm{H},{ }^{\mathrm{t}} \mathrm{Bu}\right), 1.49$ (br, $\left.18 \mathrm{H}, \mathrm{P}\left(\mathrm{CH}_{3}\right)_{3}\right), 1.58\left(\mathrm{~s}, 18 \mathrm{H}, 2 \mathrm{x}{ }^{\mathrm{t}} \mathrm{Bu}\right), 4.86$ (s, $\left.2 \mathrm{H}, \mathrm{C}_{5} \mathrm{H}_{2}{ }^{\mathrm{t}} \mathrm{Bu}_{3}\right) .{ }^{31} \mathrm{P}\left\{{ }^{1} \mathrm{H}\right\} \mathrm{NMR}\left(\mathrm{C}_{6} \mathrm{D}_{6}\right): \delta 17.9$ (s). A single crystal for the X-ray analysis was obtained by slow diffusion of a $\mathrm{MeOH}$ layer into a pentane solution at $5^{\circ} \mathrm{C}$.

Synthesis of (C5 $\left.\mathbf{H i P r}_{4}\right) \mathbf{M o}\left(\mathbf{P M e}_{2}\right)_{2} \mathbf{H}_{3}$, 2b. Compound 1b (890 mg, $\left.1.89 \mathrm{mmol}\right)$ was dissolved in tetrahydrofuran $(20 \mathrm{~mL})$, and a solution of trimethylphosphine in tetrahydrofuran ( $1 \mathrm{M}, 5 \mathrm{~mL}, 5 \mathrm{mmol}$ ) was added. The mixture was stirred for $20 \mathrm{~min}$ and a suspension of lithium tetrahydroaluminate $(c a .500 \mathrm{mg})$ in tetrahydrofuran $(40 \mathrm{~mL})$ was carefully added. Gas evolution was observed during the addition. The mixture was stirred for $6 \mathrm{~h}$, after which methanol (ca. $5 \mathrm{~mL})$ was added drop by drop. Vigorous gas evolution was observed at this point. The resulting suspension was stirred for $1 \mathrm{~h}$ and then vacuum-dried. The residue was extracted with diethyl ether ( $c a .100 \mathrm{~mL}$ ) and filtered through Celite 545. The final solution was vacuum-dried and the residue washed with portions of methanol $(5,3$ and $3 \mathrm{~mL})$ and dried in vacuo. The product $\mathbf{2 b}$ was obtained as an orange-yellow solid. Yield: $449 \mathrm{mg}$ (49 \%). Anal. Calcd. for $\mathrm{C}_{23} \mathrm{H}_{50} \mathrm{MoP}_{2}$ : C, 57.01; H, 10.40. Found: C, 56.91; H, 11.10. ${ }^{1} \mathrm{H}$ NMR $\left(\mathrm{C}_{6} \mathrm{D}_{6}\right): \delta-5.15(\mathrm{t}, J=52.9 \mathrm{~Hz}, 3 \mathrm{H}, \mathrm{Mo}-H), 1.30-1.80\left(42 \mathrm{H}, \mathrm{CH}\left(\mathrm{CH}_{3}\right)_{2}, \mathrm{P}\left(\mathrm{CH}_{3}\right)_{3}\right), 2.79(\mathrm{~m}$, $\left.2 \mathrm{H} \mathrm{CH}\left(\mathrm{CH}_{3}\right)_{2}\right), 2.96\left(\mathrm{~m}, 2 \mathrm{H} \mathrm{CH}\left(\mathrm{CH}_{3}\right)_{2}\right), 4.72\left(\mathrm{~s}, 1 \mathrm{H}, \mathrm{C}_{5} H^{\mathrm{i}} \mathrm{Pr}_{4}\right) .{ }^{31} \mathrm{P}\left\{{ }^{1} \mathrm{H}\right\} \mathrm{NMR}\left(\mathrm{C}_{6} \mathrm{D}_{6}\right): \delta$ 17.3 (s). A single crystal for the X-ray analysis was obtained by diffusion of a MeCN layer onto a THF solution at room temperature.

Synthesis of $\left[\left(1,2,4-\mathrm{C}_{5} \mathrm{H}_{2} t \mathrm{Bu}_{3}\right) \mathrm{Mo}\left(\mathrm{PMe}_{3}\right)_{2} \mathrm{H}_{3}\right]^{+} \mathbf{P F}_{6}, \mathbf{2 a}^{+} \mathbf{P F}_{6}$. A suspension of $\left[\mathrm{Fe}\left(\eta^{5}-\right.\right.$ $\left.\left.\mathrm{C}_{5} \mathrm{H}_{5}\right)_{2}\right] \mathrm{PF}_{6}(32 \mathrm{mg}, 0.10 \mathrm{mmol})$ in tetrahydrofuran $(5 \mathrm{~mL})$ was added dropwise to a cold solution $(193 \mathrm{~K})$ of compound $2 \mathbf{a}(53 \mathrm{mg}, 0.11 \mathrm{mmol})$ in tetrahydrofuran $(5 \mathrm{~mL})$. The solution color immediately changed from pale yellow to dark blue and, within a few minutes, 
to orange. The reaction mixture was slowly warmed up to $253 \mathrm{~K}$ and then concentrated to $c a$. $1 \mathrm{~mL}$. Addition of cold pentane $(253 \mathrm{~K}, 10 \mathrm{~mL})$ afforded a brown precipitate that was decanted and further washed with cold pentane $(253 \mathrm{~K}, 3 \times 10 \mathrm{~mL})$ and finally vacuum-dried. The product $\mathbf{2 a}^{+} \mathbf{P F}_{6}^{-}$was obtained as a pale brown solid. Yield: $48 \mathrm{mg}, 70 \%$. EPR (THF): $\mathrm{g}$ $=2.0185, \mathrm{aP}_{\mathrm{P}}=36.2 \mathrm{G}, \mathrm{a}_{\mathrm{H}}=11.4 \mathrm{G}, \mathrm{a}_{\mathrm{Mo}}=30.8 \mathrm{G}$. A single crystal for the X-ray analysis was obtained by diffusion of a pentane layer onto a THF solution at $-80^{\circ} \mathrm{C}$.

Synthesis of $\left[\left(1,2,4-\mathrm{C}_{5} \mathrm{H}_{2} t \mathrm{Bu}_{3}\right) \mathrm{Mo}\left(\mathrm{PMe}_{3}\right)_{2} \mathrm{H}_{4}\right]^{+} \mathrm{BF}_{4}^{-}$, 3a. A solution of $\left(\eta^{5}-\right.$ $\left.\mathrm{C}_{5} \mathrm{H}_{2}{ }^{\mathrm{t}} \mathrm{Bu}_{3}\right) \mathrm{Mo}\left(\mathrm{PMe}_{3}\right)_{2} \mathrm{H}_{3}(\mathbf{2 a}, 40 \mathrm{mg}, 0.08 \mathrm{mmol})$ in diethyl ether $(4 \mathrm{~mL})$ was cooled to $-80^{\circ} \mathrm{C}$. $\mathrm{HBF}_{4}(54 \%$ solution in diethyl ether, $22 \mu \mathrm{L}, 0.16 \mathrm{mmol})$ was added via syringe. Within minutes, a white precipitate formed. A further portion of diethyl ether $(2 \mathrm{~mL})$ was added. The solvent was then decanted and the solid washed with portions of diethyl ether $(5 \times 3 \mathrm{~mL})$ and dried under reduced pressure to yield 3a as a white solid. Yield: $39 \mathrm{mg}, 85 \%$. ${ }^{31} \mathrm{P}\left\{{ }^{1} \mathrm{H}\right\}$ NMR (THF- $\left.d_{8}\right): \delta 0.4$ (s). ${ }^{1} \mathrm{H}$ NMR (THF- $\left.d_{8}\right): \delta-4.20$ (t, $\left.J=53.4 \mathrm{~Hz}, 3 \mathrm{H}, \mathrm{Mo}-\mathrm{H}\right), 1.38$ (s, 9 $\left.\mathrm{H},{ }^{\mathrm{t}} \mathrm{Bu}\right), 1.46\left(\mathrm{~s}, 18 \mathrm{H}, 2 \times{ }^{\mathrm{t}} \mathrm{Bu}\right), 1.78\left(\mathrm{br}, 18 \mathrm{H}, \mathrm{P}\left(\mathrm{CH}_{3}\right)_{3}\right), 5.08\left(\mathrm{~s}, 2 \mathrm{H}, \mathrm{C}_{5} \mathrm{H}_{2}{ }^{\mathrm{t}} \mathrm{Bu}_{3}\right)$. A single crystal for the X-ray analysis was obtained by diffusion of a diethyl ether layer onto a THF solution at room temperature.

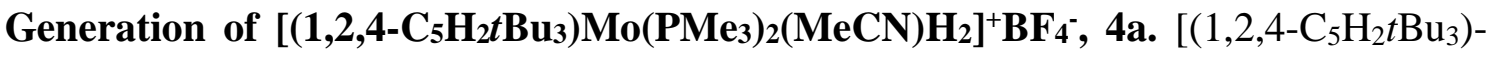
$\left.\mathrm{Mo}\left(\mathrm{PMe}_{3}\right)_{2} \mathrm{H}_{4}\right]^{+} \mathrm{BF}_{4}^{-},(3 \mathbf{a}, 10 \mathrm{mg}, 0.018 \mathrm{mmol})$ was measured into and NMR tube and dissolved in $\mathrm{CD}_{3} \mathrm{CN} .{ }^{1} \mathrm{H}$ and ${ }^{31} \mathrm{P}$ NMR spectra were recorded initially and again after $5 \mathrm{~h}$. At this time, the resonances corresponding to $\mathbf{3 a}$ were replaced by a new set of resonances, ascribed to $\left[\left(1,2,4-\mathrm{C}_{5} \mathrm{H}_{2} t \mathrm{Bu}_{3}\right) \mathrm{Mo}\left(\mathrm{PMe}_{3}\right)_{2} \mathrm{H}_{2} \mathrm{MeCN}^{+} \mathrm{BF}_{4}^{-}\right.$, 4a. ${ }^{31} \mathrm{P}\left\{{ }^{1} \mathrm{H}\right\} \mathrm{NMR}\left(\mathrm{CD}_{3} \mathrm{CN}\right): \delta 1.85$ (s). ${ }^{31} \mathrm{P}\left\{{ }^{1} \mathrm{H}\right.$ sel. decoupler at $\left.1.61 \mathrm{ppm}\right\} \delta 1.88(\mathrm{t}, \mathrm{J}=52.85 \mathrm{~Hz}){ }^{1} \mathrm{H} \mathrm{NMR}\left(\mathrm{CD}_{3} \mathrm{CN}, 298 \mathrm{~K}\right): \delta$ $1.07\left(9 \mathrm{H}, \mathrm{s}, \mathrm{C}\left(\mathrm{CH}_{3}\right)_{3}\right), 1.42,\left(18 \mathrm{H}, \mathrm{s}, 2 \times \mathrm{C}\left(\mathrm{CH}_{3}\right)_{3}\right), 1.61\left(18 \mathrm{H}, \mathrm{d}, J=8.7 \mathrm{~Hz}, \mathrm{P}\left(\mathrm{CH}_{3}\right)_{3}\right), 2.17$ $\left(3 \mathrm{H}, \mathrm{s}, \mathrm{CH}_{3} \mathrm{CN}\right) 4.59\left(\mathrm{~m}, 2 \mathrm{H}, \mathrm{C}_{5} \mathrm{H}_{2}{ }^{\mathrm{t}} \mathrm{Bu}_{4}\right) .{ }^{1} \mathrm{H} \mathrm{NMR}\left(\mathrm{CD}_{3} \mathrm{CN}, 233 \mathrm{~K}\right): \delta-6.77\left(1 \mathrm{H}, \mathrm{t}, J_{\mathrm{P}-\mathrm{H}}=\right.$ $40.0 \mathrm{~Hz}, \mathrm{Mo}-H),-0.27\left(1 \mathrm{H}, \mathrm{t}, J_{\mathrm{P}-\mathrm{H}}=80 \mathrm{~Hz}, \mathrm{Mo}-H\right), 1.03\left(9 \mathrm{H}, \mathrm{s}, \mathrm{C}\left(\mathrm{CH}_{3}\right)_{3}\right), 1.38(18 \mathrm{H}, \mathrm{s}$, 
$\left.\mathrm{C}\left(\mathrm{CH}_{3}\right)_{3}\right), 1.58\left(18 \mathrm{H}, \mathrm{d}, J_{\mathrm{P}-\mathrm{H}}=10 \mathrm{~Hz}, \mathrm{P}\left(\mathrm{CH}_{3}\right)_{3}\right), 2.40\left(3 \mathrm{H}, \mathrm{s}, \mathrm{CH}_{3} \mathrm{CN}\right), 4.58(2 \mathrm{H}, \mathrm{m}$, $\left.\mathrm{C}_{5} \mathrm{H}_{2}{ }^{\mathrm{t}} \mathrm{Bu}_{3}\right)$.

Generation of $\left[\left(\mathbf{C}_{5} \mathbf{H i P r}_{4}\right) \mathrm{Mo}\left(\mathrm{PMe}_{3}\right)_{2} \mathrm{H}_{2}(\mathrm{MeCN})\right]^{+} \mathbf{B F}_{4}^{-}, \mathbf{4 b}$. A solution of $\mathrm{HBF}_{4}(54 \%$ in diethyl ether, $7.4 \mu \mathrm{L}, 0.05 \mathrm{mmol})$ was added to a solution of $\left(\eta^{5}-\mathrm{C}_{5} \mathrm{Hi} \mathrm{Pr}_{4}\right) \mathrm{MoH}_{3}\left(\mathrm{PMe}_{3}\right)_{2}(26$ $\mathrm{mg}, 0.05 \mathrm{mmol})$ in thf $(1 \mathrm{~mL})$ and $\mathrm{MeCN}(1 \mathrm{~mL})$ at $-80^{\circ} \mathrm{C}$. A color change from yellow to orange was observed immediately. Solvents were concentrated to $1 \mathrm{~mL}$ and diethyl ether (1 $\mathrm{mL}$ ) was added to aid the precipitation of a yellow solid. The solution was filtered and the solid washed with portions of diethyl ether $(5 \times 2 \mathrm{~mL})$ and dried under reduced pressure to give $4 \mathbf{b}$ as a yellow solid. ${ }^{31} \mathrm{P}\left\{{ }^{1} \mathrm{H}\right\}$ NMR (acetone- $\left.d_{6}\right): \delta 4.66(\mathrm{~s}) .{ }^{31} \mathrm{P}\left\{{ }^{1} \mathrm{H}\right.$ sel. decoupler at $1.68 \mathrm{ppm}\} \delta 4.68(\mathrm{t}, \mathrm{J}=54.7 \mathrm{~Hz}){ }^{1} \mathrm{H}$ NMR (acetone- $\left.d_{6}, 298 \mathrm{~K}\right): \delta-2.5(\mathrm{br}, 2 \mathrm{H}, \mathrm{Mo}-H), 1.18$ $\left(12 \mathrm{H}, \mathrm{d}, J=8.2 \mathrm{~Hz}, \mathrm{CH}\left(\mathrm{CH}_{3}\right)_{2}\right), 1.31,\left(12 \mathrm{H}, \mathrm{d}, J=8.6 \mathrm{~Hz}, \mathrm{CH}\left(\mathrm{CH}_{3}\right)_{2}\right), 1.69(18 \mathrm{H}, \mathrm{d}$, $\left.\mathrm{P}\left(\mathrm{CH}_{3}\right)_{3}\right), 2.71\left(7 \mathrm{H}, \mathrm{m}, \mathrm{CH}\left(\mathrm{CH}_{3}\right)_{2}, \mathrm{CH}_{3} \mathrm{CN}\right) 4.92\left(\mathrm{~s}, 1 \mathrm{H}, \mathrm{C}_{5} H^{\mathrm{i}} \mathrm{Pr}_{4}\right) .{ }^{1} \mathrm{H}$ NMR (acetone- $d_{6}, 200$ $\mathrm{K}): \delta-5.27\left(1 \mathrm{H}, \mathrm{td}, J_{\mathrm{P}-\mathrm{H}}=32.5 \mathrm{~Hz}, J_{\mathrm{H}-\mathrm{H}}=10 \mathrm{~Hz}\right.$ Mo- $\left.H\right),-0.13\left(1 \mathrm{H}, \mathrm{ddd}, J_{\mathrm{P}-\mathrm{H}}=47.5,33.75\right.$, $\left.J_{\mathrm{H}-\mathrm{H}}=10 \mathrm{~Hz}, \mathrm{Mo}-H\right), 1.07\left(3 \mathrm{H}, \mathrm{d}, J=6.8 \mathrm{~Hz}, \mathrm{CH}\left(\mathrm{CH}_{3}\right)_{2}\right), 1.13(3 \mathrm{H}, \mathrm{d}, J=6.8 \mathrm{~Hz}$, $\left.\mathrm{CH}\left(\mathrm{CH}_{3}\right)_{2}\right), 1.18-1.23\left(9 \mathrm{H}, 3 \mathrm{x} \mathrm{d}, J=7.3,6.9 \mathrm{~Hz}, \mathrm{CH}\left(\mathrm{CH}_{3}\right)_{2}\right), 1.29(3 \mathrm{H}, \mathrm{d}, J=7.3 \mathrm{~Hz}$, $\left.\mathrm{CH}\left(\mathrm{CH}_{3}\right)_{2}\right), 1.39\left(6 \mathrm{H}, 2 \mathrm{x} \mathrm{d}, J=6.5 \mathrm{~Hz}, \mathrm{CH}\left(\mathrm{CH}_{3}\right)_{2}\right), 1.65\left(18 \mathrm{H}, 2 \mathrm{x} \mathrm{d}, J_{\mathrm{P}-\mathrm{H}}=8.0 \mathrm{~Hz}, \mathrm{P}\left(\mathrm{CH}_{3}\right)_{3}\right)$, $2.53\left(1 \mathrm{H}, \mathrm{m}, J=6.8 \mathrm{~Hz}, \mathrm{CH}\left(\mathrm{CH}_{3}\right)_{2}\right), 2.58\left(1 \mathrm{H}, \mathrm{m}, J=7.3 \mathrm{~Hz}, \mathrm{CH}\left(\mathrm{CH}_{3}\right)_{2}\right), 2.71(2 \mathrm{H}, 2 \mathrm{x}$ $\left.\mathrm{CH}\left(\mathrm{CH}_{3}\right)_{2}, \mathrm{~m}, J=6.5 \mathrm{~Hz}\right), 2.79\left(3 \mathrm{H}, \mathrm{s}, \mathrm{CH}_{3} \mathrm{CN}\right), 5.02\left(1 \mathrm{H}, \mathrm{d}, J=6 \mathrm{~Hz}, \mathrm{C}_{5} H^{\mathrm{i}} \mathrm{Pr}_{4}\right)$.

Formation of $\left[\left(1,2,4-\mathrm{C}_{5} \mathrm{H}_{2} t \mathrm{Bu}_{3}\right) \mathrm{Mo}\left(\mathrm{PMe}_{3}\right)_{2} \mathrm{H}^{+}\right]^{+} \mathrm{PF}_{6}$ ', 5. A solution of compound $\mathbf{2 a}^{+} \mathbf{P F}_{6}{ }^{-}$in THF was stored at $-20^{\circ} \mathrm{C}$ for 2 days, after which time a mixture of green and dark orange-red crystals had formed. One of the green crystals was used for the X-ray analysis. For the spectroscopic properties, see Results and Discussion.

Single crystal X-ray and neutron diffraction studies. A single crystal of each compound was mounted under inert perfluoropolyether at the tip of glass fibre and cooled in the cryostream of either an Oxford-Diffraction XCALIBUR CCD diffractometer for $\mathbf{2 b}, \mathbf{4 a}$ 
and $\mathbf{5 a}$ or a Stoe IPDS diffractometer for $\mathbf{2 a}, \mathbf{2 a}^{+}$. Data were collected using the monochromatic MoK $\alpha$ radiation $(\lambda=0.71073)$. The structures were solved by direct methods $\left(\right.$ SIR97) ${ }^{[55]}$ and refined by least-squares procedures on $F^{2}$ using SHELXL-97. ${ }^{[56]}$ All H atoms attached to carbon were introduced in calculation in idealised positions and treated as riding models. In compound $\mathbf{2 a}^{+}$, there are two cations and anions in the asymmetric unit and all the $t \mathrm{Bu}$ groups of one of the cations are disordered over two positions. In structure $\mathbf{2 a}$, coordinates and $\mathrm{U}_{\text {iso }}$ for the hydrides, were fully refined whereas in $\mathbf{3 a}$, the coordinates of the hydrides were fully refined with an overall isotropic thermal parameter. In $\mathbf{2 a}^{+}$and $\mathbf{5 a}$, the coordinates of the hydrides were fully refined with $\mathrm{U}_{\mathrm{iso}}=1.2 \mathrm{U}_{\text {eq }}\left[\mathrm{Mo}\left(\mathbf{2} \mathbf{a}^{+}\right)\right]$or $\mathrm{U}_{\text {iso }}=1.5 \mathrm{U}_{\text {eq }}[\mathrm{Mo}(\mathbf{5 a})]$. The disordered moieties were refined applying the restraints available within SHELXL97. ${ }^{[56]}$ Moreover, some residual electron density was difficult to model and therefore, the SQUEEZE function of PLATON ${ }^{[57]}$ was used to eliminate the contribution of the electron density in the solvent region from the intensity data, and the solvent-free model was employed for the final refinement. There are four cavities per unit cell and PLATON estimated that each cavity contains 32 electrons which could be attributed to a disordered THF molecules. The data collected for compound $\mathbf{2} \mathbf{b}$ were of very low quality and although the structural model is mainly correct, it was not possible to locate any hydride ligand. The drawing of the molecules was realised with the help of ORTEP32. ${ }^{[58]}$ Crystal data and refinement parameters are shown in Table 2.

The neutron single-crystal diffraction study was performed using the time-of-flight Laue diffractometer SXD ${ }^{[59]}$ installed at the ISIS pulsed spallation source. SXD uses the white beam Laue technique and a stationary crystal combined with eleven highly pixellated area detectors covering around half a sphere around the sample. Thus, large volumes in reciprocal space can be collected in a single shot. A suitable single crystal of the complex (2a) was fixed to an Aluminum pin with thin strips of adhesive Al tape and mounted on a He closed-cycle 
refrigerator and cooled slowly to $20 \mathrm{~K}$. The space group $\mathrm{P} 2{ }_{1} / \mathrm{n}$ was confirmed at $20 \mathrm{~K}$. No significant change in the crystal mosaic or splitting of the peak was observed during cooling. Further crystallographic data and experimental details are given in Table 2 and in the Supporting Information. The unit cell dimensions were precisely calculated, at the end of the data collection, from the positions of 60 reflections per each detector orientation. Data were collected at nine different orientations at 20(1) K for ca. 24 hour per orientation. The range of wavelengths used for the data collection was $0.37<\lambda<8.8 \AA$, even though the bulk of the diffraction information is obtained from the wavelength range $0.5<\lambda<7.0 \AA$. Data reduction and a Gaussian absorption correction were performed using the standard SXD procedure implemented in the SXD2001 software ${ }^{[60]}$ resulting in a total of 8686 reflections of which 3203 were unique. The starting structural model for the refinement was based on the atomic co-ordinates for the non hydrogen atoms taken from the X-ray structural determination. The structure was refined by full matrix least squares, minimising the function $\left[\sum w\left(F_{\mathrm{o}}^{2}-\right.\right.$ $\left.\left.(1 / k) F_{\mathrm{c}}\right)^{2}\right]$ and using all independent data. During the refinement, the difference-Fourier maps clearly showed all $\mathrm{H}$ atoms of the ligands and the three hydrides. The final structure model included co-ordinates and anisotropic displacement parameters for all atoms. Upon convergence the final Fourier difference map showed no significant features. The coherent scattering amplitudes used were those tabulated by Rauch and Waschkowski. ${ }^{[61]}$ All calculations were carried out by using the PC version of the programs WINGX, ${ }^{[62]}$ SHELX$97^{[56]}$ and ORTEP. ${ }^{[58]}$

Crystallographic data (excluding structure factors) have been deposited with the Cambridge Crystallographic Data Centre as supplementary publication no. CCDC 631893 631898. Copies of the data can be obtained free of charge on application to the Director, CCDC, 12 Union Road, Cambridge CB2 1EZ, UK (Fax: (+44) 1223-336-033; E-mail: deposit@ccdc.cam.ac.uk). 


\section{Acknowledgements}

We thank the European Commission through the HYDROCHEM program (contract HPRN-CT-2002-00176) for support of this work. MB thanks the Spanish Ministerio de Educación y Ciencia for a post-doctoral fellowship.

\section{Supporting Information available}

Figures showing the structure of 2a from the neutron diffraction experiment, the variable

temperature ${ }^{31} \mathrm{P}\left\{{ }^{1} \mathrm{H}\right\}$ experiment for compound $\mathbf{2} \mathbf{b}$, and a variety of cyclic voltammograms for $\mathbf{2 a}$ and $\mathbf{2 b}$ at variable scan speed in $\mathrm{MeCN}$ and THF (5 pages). 


\section{References}

[1] G. W. Parshall, Homogeneous Catalysis: The Applications and Chemistry of Catalysis by Soluble Transition Metal Complexes, John Wiley and Sons, New York, 1980.

[2] A. Dedieu, Transition Metal Hydrides, VCH, New York, 1992.

[3] M. Peruzzini, R. Poli, Recent Advances in Hydride Chemistry, Elsevier, Amsterdam, 2001.

[4] R. Y. Igarashi, M. Laryukhin, P. C. Dos Santos, H.-I. Lee, D. R. Dean, L. C. Seefeldt, B. M. Hoffman, J. Am. Chem. Soc. 2005, 127, 6231-6241.

[5] S. Foerster, M. Stein, M. Brecht, H. Ogata, Y. Higuchi, W. Lubitz, J. Am. Chem. Soc. 2003, 125, 83-93.

[6] R. Mejia-Rodriguez, D. S. Chong, J. H. Reibenspies, M. P. Soriaga, M. Y. Darensbourg, J. Am. Chem. Soc. 2004, 126, 12004-12014.

[7] O. B. Ryan, M. Tilset, V. D. Parker, J. Am. Chem. Soc. 1990, 112, 2618-2626.

[8] K.-T. Smith, C. Rømming, M. Tilset, J. Am. Chem. Soc. 1993, 115, 8681-8689.

[9] B. Pleune, D. Morales, R. Meunier-Prest, P. Richard, E. Collange, J. C. Fettinger, R. Poli, J. Am. Chem. Soc. 1999, 121, 2209-2225.

[10] V. Skagestad, M. Tilset, J. Am. Chem. Soc. 1993, 115, 5077-5083.

[11] R. Poli, in Recent Advances in Hydride Chemistry (Eds.: R. Poli, M. Peruzzini), Elsevier Science, Amsterdam, 2001, pp. 139-188.

[12] B. Pleune, R. Poli, J. C. Fettinger, J. Am. Chem. Soc. 1998, 120, 3257-3258.

[13] E. A. Quadrelli, H.-B. Kraatz, R. Poli, Inorg. Chem. 1996, 35, 5154-5162.

[14] J. C. Fettinger, H.-B. Kraatz, R. Poli, E. A. Quadrelli, R. C. Torralba, Organometallics 1998, 17, 5767-5775.

[15] E. A. Quadrelli, R. Poli, Organometallics 1998, 17, 5776-5781.

[16] R. Poli, M. Baya, R. Meunier-Prest, S. Raveau, New J. Chem. 2006, 30, 759 - 773.

[17] A. A. Zlota, M. Tilset, K. G. Caulton, Inorg. Chem. 1993, 32, 3816-3821.

[18] A. Pedersen, M. Tilset, Organometallics 1994, 13, 4887-4894.

[19] M. T. Costello, R. A. Walton, Inorg. Chem. 1988, 27, 2563-2564.

[20] K.-T. Smith, M. Tilset, R. Kuhlman, K. G. Caulton, J. Am. Chem. Soc. 1995, 117, 9473-9480.

[21] M. Baya, J. Houghton, J.-C. Daran, R. Poli, Angew. Chem., Int. Ed. Engl. 2007, 46, 429-432.

[22] R. C. Murray, L. Blum, A. H. Liu, R. R. Schrock, Organometallics 1985, 4, 953-954.

[23] D. W. Keogh, R. Poli, in Synthetic Methods of Organometallic and Inorganic

Chemistry (Herrmann/Brauer), Vol. 8 (Ed.: W. A. Herrmann), Georg Thieme Verlag, Stuttgart, 1997, p. 98.

[24] J. H. Shin, G. Parkin, Chem. Commun. 1998, 1273-1274.

[25] J. C. Fettinger, B. Pleune, R. Poli, J. Am. Chem. Soc. 1996, 118, 4906-4907.

[26] B. Pleune, R. Poli, J. C. Fettinger, Organometallics 1997, 16, 1581-1594.

[27] H. Sakaba, T. Hirata, C. Kabuto, K. Kabuto, Organometallics 2006, 25, 5145-5150.

[28] G. J. Kubas, Metal Dihydrogen and $\sigma$-Bond Complexes, Kluwer Academic/Plenum Press, New York, 2001.

[29] D. M. Heinekey, J. M. Millar, T. F. Koetzle, N. G. Payne, K. W. Zilm, J. Am. Chem. Soc. 1990, 112, 909-919.

[30] J. A. K. Howard, O. Johnson, T. F. Koetzle, J. L. Spencer, Inorg. Chem. 1987, 26, 2930-2933. 
[31] J. A. K. Howard, S. A. Mason, O. Johnson, I. C. Diamond, S. Crennell, P. A. Keller, J. L. Spencer, J. Chem. Soc., Chem. Comm. 1988, 1502-1503.

[32] L. Brammer, J. A. K. Howard, O. Johnson, T. F. Koetzle, J. L. Spencer, A. M. Stringer, J. Chem. Soc., Chem. Commun. 1991, 241-243.

[33] T. Hasegawa, Z. Li, S. Parkin, H. Hope, R. K. McMullan, T. F. Koetzle, H. Taube, J. Am. Chem. Soc. 1994, 116, 4352-4356.

[34] T. J. Johnson, A. Albinati, T. F. Koetzle, J. Ricci, O. Eisenstein, J. C. Huffman, K. G. Caulton, Inorg. Chem. 1994, 33, 4966-4976.

[35] T. M. Cameron, C. G. Ortiz, I. Ghiviriga, K. A. Abboud, J. M. Boncella, J. Am. Chem. Soc. 2002, 124, 922-923.

[36] R. Poli, Organometallics 1990, 9, 1892-1900.

[37] F. Abugideiri, J. C. Fettinger, D. W. Keogh, R. Poli, Organometallics 1996, 15, 44074416.

[38] T.-Y. Cheng, D. J. Szalda, J. Zhang, R. M. Bullock, Inorg. Chem. 2006, 45, 47124720.

[39] D. M. Heinekey, A. Lledós, J. M. Lluch, Chem. Soc. Rev. 2004, 175-182.

[40] J. Sandström, Dynamic NMR Spectroscopy, Academic Press, London, 1982.

[41] G. Binsch, J. Am. Chem. Soc. 1969, 91, 1304-1309.

[42] R. Poli, Chem. Rev. 1996, 96, 2135-2204.

[43] R. Poli, J. Organometal. Chem 2004, 689, 4291-4304.

[44] D. G. Morrell, J. K. Kochi, J. Am. Chem. Soc. 1975, 97, 7262-7270.

[45] T. T. Tsou, J. K. Kochi, J. Am. Chem. Soc. 1978, 100, 1634-1635.

[46] W. Lau, J. C. Huffman, J. K. Kochi, Organometallics 1982, 1, 155-169.

[47] A. Pedersen, M. Tilset, Organometallics 1993, 12, 56-64.

[48] P. Diversi, S. Iacoponi, G. Ingrosso, F. Laschi, A. Lucherini, C. Pinzino, G. UccelloBarretta, P. Zanello, Organometallics 1995, 14, 3275-3287.

[49] E. Fooladi, M. Tilset, Inorg. Chem. 1997, 36, 6021-6027.

[50] E. Fooladi, T. Graham, M. L. Turner, B. Dalhus, P. M. Maitlis, M. Tilset, J. Chem. Soc., Dalton Trans. 2002, 975-982.

[51] H. Sitzmann, J. Organometal. Chem. 1988, 354, 203-214.

[52] H. Sitzmann, Z. Naturforsch. 1989, 44b, 1293-1297.

[53] K. Marat, SpinWorks Version 2.5.4, 2006.

[54] D. R. Duling, P.E.S.T., v. 0.96, National Institute of Environmental Health Sciences, Research Triangle Park, NC, 1996.

[55] A. Altomare, M. Burla, M. Camalli, G. Cascarano, C. Giacovazzo, A. Guagliardi, A. Moliterni, G. Polidori, R. Spagna, J. Appl. Cryst. 1999, 32, 115-119.

[56] G. M. Sheldrick, SHELXL97. Program for Crystal Structure refinement, University of Göttingen, Göttingen, Germany, 1997.

[57] A. L. Spek, J. Appl. Cryst. 2003, 36, 7-13.

[58] L. J. Farrugia, J. Appl. Crystallogr. 1997, 32, 565.

[59] D. A. Keen, M. J. Gutmann, C. C. Wilson, J. Appl. Cryst. 2006, 39, 714.

[60] M. J. Gutmann, ISIS Facility, Rutherford Appleton Laboratory, U.K., 2006.

[61] H. Rauch, W. Waschkowski, in Neutron Data Booklet (Eds.: A. J. Dianoux, G. Lander), Institut Laue-Langevin: Grenoble, 2002, pp. 1.1-1.

[62] L. J. Farrugia, J. Appl. Crystallogr. 1999, 32, 837-838. 
Table 1. Selected bond distances $(\AA)$ and angles $\left(^{\circ}\right)$ for all structurally characterized complexes

\begin{tabular}{|c|c|c|c|c|c|c|c|}
\hline & \multicolumn{2}{|c|}{$2 \mathbf{a}$} & \multirow{2}{*}{$\frac{\mathbf{2 b}}{\text { X-ray }}$} & \multirow{2}{*}{$\begin{array}{c}\mathbf{3 a} \\
\text { X-ray }\end{array}$} & \multirow{2}{*}{\multicolumn{2}{|c|}{$\frac{\mathbf{2 a}^{+}}{\mathrm{X}-\mathrm{ray}^{\mathrm{a}}}$}} & $5 \mathbf{5}$ \\
\hline & X-ray & neutron & & & & & X-ray \\
\hline $\mathrm{Mo}^{-\mathrm{CNT}^{\mathrm{b}}}$ & $2.0150(2)$ & $2.019(5)$ & $2.013(1)$ & $2.0100(2)$ & $1.9992(4)$ & $2.0036(4)$ & $2.0096(3)$ \\
\hline Mo-P(1) & $2.3832(6)$ & $2.385(5)$ & $2.377(4)$ & $2.4656(7)$ & $2.4720(14)$ & $2.4744(15)$ & $2.4801(8)$ \\
\hline Mo-P(2) & $2.3801(6)$ & $2.377(5)$ & $2.375(4)$ & $2.4720(7)$ & $2.4738(14)$ & $2.4726(15)$ & $2.4685(9)$ \\
\hline Mo-H(1) & $1.58(3)$ & $1.712(8)$ & & $1.67(3)$ & $1.65(4)$ & $1.60(4)$ & $1.83(3)$ \\
\hline Mo-H(2) & $1.57(3)$ & $1.719(9)$ & & $1.58(3)$ & $1.52(4)$ & $1.56(4)$ & \\
\hline Mo-H(3) & $1.58(3)$ & $1.719(9)$ & & 1.61(3) & $1.54(4)$ & $1.60(4)$ & \\
\hline Mo-H(4) & & & & $1.66(3)$ & & & \\
\hline $\mathrm{H}(2) \cdots \mathrm{H}(3)$ & $1.63(4)$ & $1.69(2)$ & & & $1.33(6)$ & $1.38(6)$ & \\
\hline CNT-Mo-P(1) & $130.62(2)$ & $130.7(2)$ & $133.8(1)$ & $120.339(18)$ & $127.80(4)$ & $126.13(4)$ & $122.02(2)$ \\
\hline CNT-Mo-P(2) & $132.14(2)$ & $132.1(2)$ & $131.5(1)$ & $120.808(18)$ & $127.16(4)$ & $127.74(4)$ & $121.57(2)$ \\
\hline CNT-Mo-H(1) & $106(1)$ & $105.8(3)$ & & $108.5(9)$ & $105(2)$ & 104(2) & $125.2(9)$ \\
\hline CNT-Mo-H(2) & 107(1) & $106.0(3)$ & & 104.9(9) & 107(2) & $110(2)$ & \\
\hline CNT-Mo-H(3) & 114(1) & $115.1(3)$ & & 104.7(9) & $106(2)$ & 109(2) & \\
\hline CNT-Mo-H(4) & & & & 173.1(9) & & & \\
\hline $\mathrm{P}(1)-\mathrm{Mo}-\mathrm{P}(2)$ & $93.71(2)$ & $93.6(2)$ & $94.02(14)$ & $112.09(2)$ & $100.25(6)$ & $100.42(6)$ & $109.55(3)$ \\
\hline $\mathrm{H}(2)-\mathrm{Mo}-\mathrm{H}(3)$ & $62(2)$ & $58.9(5)$ & & & $51(2)$ & $52(2)$ & \\
\hline
\end{tabular}

${ }^{a}$ The parameters of each crystallographically independent molecule are shown in separate columns. ${ }^{b} \mathrm{CNT}$ is the centroid of the Cp ring. 
Table 2. Crystal data and structure refinement for all structurally characterized complexes

\begin{tabular}{|c|c|c|c|c|c|c|}
\hline Identification code & 2a (X-ray) & 2a (neutron) & $2 \mathrm{~b}$ & $\mathbf{3 a}$ & $2 a^{+}$ & $5 \mathbf{a}$ \\
\hline Empirical formula & $\mathrm{C}_{23} \mathrm{H}_{50} \mathrm{MoP}_{2}$ & $\mathrm{C}_{23} \mathrm{H}_{50} \mathrm{MoP}_{2}$ & $\mathrm{C}_{23} \mathrm{H}_{50} \mathrm{MoP}_{2}$ & $\mathrm{C}_{23} \mathrm{H}_{51} \mathrm{BF}_{4} \mathrm{MoP}_{2}$ & $\mathrm{C}_{23} \mathrm{H}_{50} \mathrm{~F}_{6} \mathrm{MoP}_{3}$ & $\mathrm{C}_{23} \mathrm{H}_{48} \mathrm{~F}_{6} \mathrm{MoP}_{3}$ \\
\hline Formula weight & 484.51 & 484.51 & 481.49 & 572.33 & 629.48 & 627.46 \\
\hline Temperature, $\mathrm{K}$ & $180(2)$ & $20(1)$ & $180(2)$ & $180(2)$ & $180(2)$ & $180(2)$ \\
\hline Wavelength, $\AA$ & 0.71073 & $0.37-8.8$ & 0.71073 & 0.71073 & 0.71073 & 0.71073 \\
\hline Crystal system & Monoclinic & Monoclinic & Monoclinic & Monoclinic & Monoclinic & Monoclinic \\
\hline Space group & $\mathrm{P} 22_{1} / \mathrm{n}$ & $\mathrm{P} 2{ }_{1} / \mathrm{n}$ & $\mathrm{P} 2{ }_{1} / \mathrm{c}$ & $\mathrm{P} 2{ }_{1} / \mathrm{c}$ & $\mathrm{P} 2{ }_{1} / \mathrm{c}$ & $\mathrm{P} 2{ }_{1} / \mathrm{c}$ \\
\hline $\mathrm{a}, \AA$ & $16.2915(15)$ & $16.238(5)$ & $15.599(4)$ & $9.3986(5)$ & $14.0847(10)$ & $9.6185(5)$ \\
\hline $\mathrm{b}, \AA$ & $17.4655(16)$ & $17.392(5)$ & $10.2114(18)$ & $16.9428(8)$ & $26.216(2)$ & $16.8699(10)$ \\
\hline c, $\AA$ & $9.2144(8)$ & $9.160(4)$ & $16.939(4)$ & $18.2340(9)$ & $20.1855(15)$ & $18.7489(12)$ \\
\hline$\alpha,{ }^{\circ}$ & 90.0 & 90.0 & 90.0 & 90.0 & 90.0 & 90.0 \\
\hline$\beta,{ }^{\circ}$ & $92.651(10)$ & $92.83(1)$ & $103.51(2)$ & $92.719(4)$ & $99.221(8)$ & $90.441(5)$ \\
\hline$\gamma^{\circ}$ & 90.0 & 90.0 & 90.0 & 90.0 & 90.0 & 90.0 \\
\hline $\mathrm{V}, \AA^{3}$ & $2619.1(4)$ & $2584(2)$ & $2623.5(10)$ & $2900.3(3)$ & $7357.2(10)$ & $3042.2(3)$ \\
\hline $\mathrm{Z}$ & 4 & 4 & 4 & 4 & 8 & 4 \\
\hline Dcalc, $\mathrm{Mg} / \mathrm{m}^{3}$ & 1.229 & 1.246 & 1.227 & 1.311 & 1.269 & 1.370 \\
\hline$\mu, \mathrm{mm}^{-1}$ & 0.629 & $0.0655+0.0002 \lambda$ & 0.628 & 0.597 & 0.535 & 0.636 \\
\hline Crystal size, $\mathrm{mm}^{3}$ & $0.27 \times 0.23 \times 0.2$ & $2.2 \times 1.6 \times 1.4$ & $0.13 \times 0.1 \times 0.1$ & $0.25 \times 0.21 \times 0.13$ & $0.2 \times 0.1 \times 0.1$ & $0.58 \times 0.42 \times 0.24$ \\
\hline$\theta^{\circ}$, range & 2.49 to 26.18 & 8.52 to 81.95 & 3.17 to 23.20 & 2.76 to 28.22 & 2.14 to $25.00^{\circ}$ & 3.25 to 26.37 \\
\hline Reflections collected & 20750 & 8686 & 14396 & 24326 & 50093 & 27114 \\
\hline Indpnt refl [Rint] & $5171[0.0337]$ & $3203[0.141]$ & $3766[0.1239]$ & 7190 [0.0392] & $12934[0.0853]$ & 18993 [0.0513] \\
\hline Absorption correction & Multi-scan & Gaussian & Multi-scan & Multi-scan & Multi-scan & Multi-scan \\
\hline Max. and min. transm. & $0.8299,0.7768$ & $1.5609,1.626$ & $1.0214,0.8735$ & $0.9996,0.8209$ & $0.8843,0.8674$ & $0.8363,0.7206$ \\
\hline
\end{tabular}




\begin{tabular}{|c|c|c|c|c|c|c|}
\hline Refinement method & $\mathrm{F}^{2}$ & $\mathrm{~F}^{2}$ & $\mathrm{~F}^{2}$ & $\mathrm{~F}^{2}$ & $\mathrm{~F}^{2}$ & $\mathrm{~F}^{2}$ \\
\hline Data / restraints / parameters & $5171 / 0 / 262$ & $3203 / 0 / 686$ & $3766 / 204 / 249$ & $7190 / 0 / 308$ & $12934 / 216 / 763$ & $18993 / 0 / 317$ \\
\hline GOF on $\mathrm{F}^{2}$ & 1.034 & 1.023 & 1.129 & 1.013 & 0.835 & 1.070 \\
\hline $\mathrm{R} 1, \mathrm{wR} 2[\mathrm{I}>2 \sigma(\mathrm{I})]$ & $0.0270,0.0657$ & $0.0603,0.1542$ & $0.1029,0.2176$ & $0.0333,0.0788$ & $0.0488,0.1052$ & $0.0507,0.1428$ \\
\hline R1, wR2 (all data) & $0.0357,0.0708$ & $0.0608,0.1546$ & $0.1592,0.2396$ & $0.0508,0.0901$ & $0.0963,0.1174$ & $0.0599,0.1554$ \\
\hline
\end{tabular}




\section{Synopsis}

Sterically protecting cyclopentadienyl ligands in combination with $\mathrm{PMe}_{3}$ yield relatively stable paramagnetic half-sandwich trihydride complexes of molybdenum, showing evidence of an incipient $\mathrm{H}-\mathrm{H}$ interaction. Subsequent $\mathrm{H}_{2}$ elimination yields a stable spin quartet 15electron hydride complex, providing the first well defined example of an oxidatively induced reductive elimination of dihydrogen.

Table of Contents Graphics

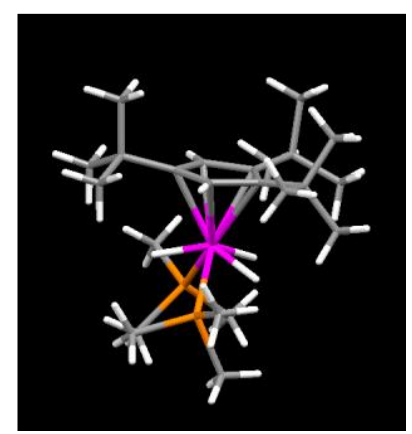

"Molv"

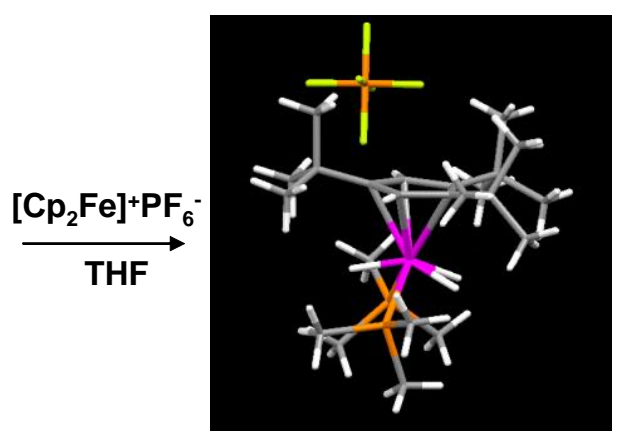

$$
\text { "Mov" }
$$

Stable below room temperature $(S=1 / 2)$

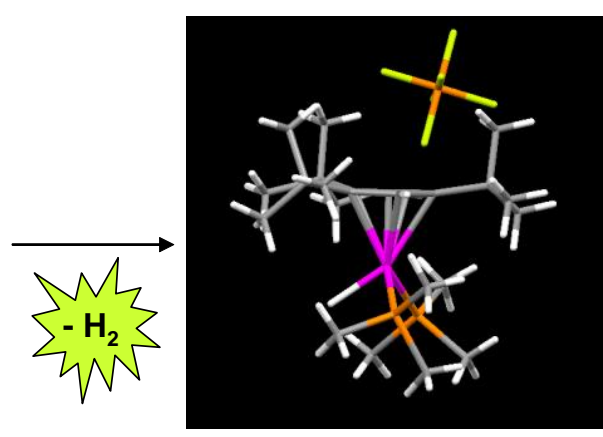

"Mo"II")

Stable 15-electrons hydride complex $(S=3 / 2)$ 